\title{
Mutual Interactions between Brain States and Alzheimer's Disease Pathology: A Focus on Gamma and Slow Oscillations
}

\author{
Nicole Byron, Anna Semenova and Shuzo Sakata*
}

check for

updates

Citation: Byron, N.; Semenova, A.; Sakata, S. Mutual Interactions between Brain States and Alzheimer's Disease Pathology: A Focus on Gamma and Slow Oscillations. Biology 2021, 10, 707 https://doi.org/10.3390/ biology10080707

Academic Editors: Xinhua Shu, Zhiming He and Mustafa Nazıroglu

Received: 8 June 2021

Accepted: 21 July 2021

Published: 23 July 2021

Publisher's Note: MDPI stays neutral with regard to jurisdictional claims in published maps and institutional affiliations.

Copyright: (c) 2021 by the authors. Licensee MDPI, Basel, Switzerland. This article is an open access article distributed under the terms and conditions of the Creative Commons Attribution (CC BY) license (https:/ / creativecommons.org/licenses/by/ $4.0 /)$.
Strathclyde Institute of Pharmacy and Biomedical Sciences, University of Strathclyde, 161 Cathedral Street, Glasgow G4 0RE, UK; nicole.byron.2015@uni.strath.ac.uk (N.B.); anna.semenova.2020@uni.strath.ac.uk (A.S.)

* Correspondence: shuzo.sakata@strath.ac.uk

Simple Summary: Electrical activity in the brain dynamically changes throughout the day. Abnormalities in brain activity have been associated with various brain disorders, including Alzheimer's disease (AD). While brain disorders stem from complex pathological processes, resulting in abnormalities in neural activity and cognitive deficits, recent studies have demonstrated that controlling brain activity can modify disease pathologies as well as cognitive functions. In particular, studies in mouse models of $\mathrm{AD}$ have provided promising results regarding the amelioration of AD pathology by invasive and non-invasive brain stimulations. In this review article, by focusing on AD, we provide an overview of this emerging field. We summarise how brain activity changes in humans and mouse models, and how different artificial manipulations of brain activity can modify AD pathology. Although further investigations are essential, this research direction will provide insight into non-pharmacological intervention strategies for dementia.

Abstract: Brain state varies from moment to moment. While brain state can be defined by ongoing neuronal population activity, such as neuronal oscillations, this is tightly coupled with certain behavioural or vigilant states. In recent decades, abnormalities in brain state have been recognised as biomarkers of various brain diseases and disorders. Intriguingly, accumulating evidence also demonstrates mutual interactions between brain states and disease pathologies: while abnormalities in brain state arise during disease progression, manipulations of brain state can modify disease pathology, suggesting a therapeutic potential. In this review, by focusing on Alzheimer's disease (AD), the most common form of dementia, we provide an overview of how brain states change in AD patients and mouse models, and how controlling brain states can modify AD pathology. Specifically, we summarise the relationship between AD and changes in gamma and slow oscillations. As pathological changes in these oscillations correlate with AD pathology, manipulations of either gamma or slow oscillations can modify AD pathology in mouse models. We argue that neuromodulation approaches to target brain states are a promising non-pharmacological intervention for neurodegenerative diseases.

Keywords: dementia; Alzheimer's disease; neuromodulation; neural oscillations; optogenetics

\section{Introduction}

The brain is never at rest. The activity state of the brain, called the brain state, varies from moment to moment. While brain state can be defined as a collective action of the neural population at a given moment, it spans over multiple spatiotemporal scales (Figure 1) [1-3]. Hans Berger first described the 8-12 Hz rhythm, called alpha waves, in a human scalp electroencephalogram (EEG) recording [4]. Since then, intensive research has discovered a wide range of activity patterns or brain states (Figure 1A). For example, gamma (30-90 Hz) oscillations are a fast activity state and appear locally, compared to slower frequency oscillations. Gamma oscillations are related to various cognitive functions, such as attention, conscious perception and memory [5-12]. The sleep-wake cycle can be 
considered as slower state changes and consists of multiple neural events and oscillations (Figure 1). Rapid eye movement (REM) sleep is characterised by theta oscillations and ponto-geniculo-occipital (PGO) waves, whereas non-REM (NREM) sleep is characterised by slow oscillations, sleep spindles, and sharp wave-ripples [13-21] (Figure 1B). These sleeprelated neural events or oscillations have also been implicated in various homeostatic and cognitive functions, including waste clearance [22,23] and memory consolidation [24-29].

A

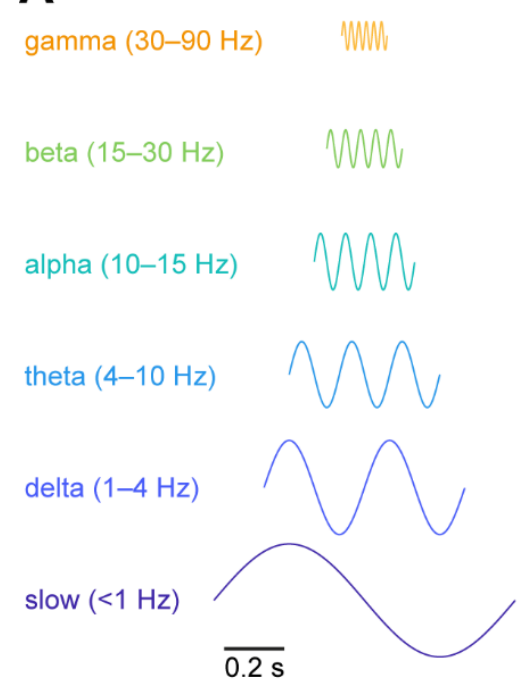

B

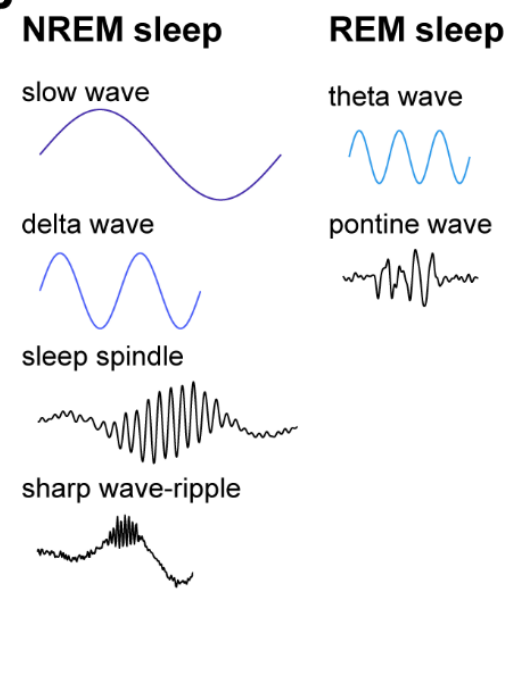

Figure 1. Neural oscillations and events across brain states. (A) Neural oscillations and their frequency band. (B) Characteristic neural oscillations and events during sleep states.

Given the prominence of these neural oscillations and events, it is not surprising that consistent associations can be seen between various brain disorders and abnormalities in neural oscillations or brain states [30-34]. For example, abnormalities in gamma oscillations have been recognised as a neurophysiological marker for various neuropsychiatric disorders and neurodegenerative diseases, such as schizophrenia [34], autism spectrum disorder (ASD) [35,36], depression [37,38], and Alzheimer's disease (AD) [31]: more specifically, a reduction in sensory-evoked gamma power can be seen in schizophrenia and ASD patients, whereas varied changes in gamma oscillations have been reported in depressive disorders and AD patients [34,36,38-41]. Additionally, abnormalities in sleep patterns and sleep-related oscillations have been linked with depression [42], schizophrenia [43,44], addiction [45] and AD [46-49].

Although it remains to be determined how abnormalities in brain states can be causally linked to disease pathogenesis, an emerging approach, called "neuromodulation", aims to alter neural activity to modify disease state [50]. For example, while deep brain stimulation (DBS) is an invasive approach, chronically implanting a depth electrode into the patient brain to electrically stimulate a target brain region, it can alleviate the symptoms of Parkinson's disease [51,52] and has also been examined in treatment-resistant depression [53,54], obsessive-compulsive disorder [55,56] and AD [57,58]. In addition to invasive treatment, non-invasive neuromodulation approaches, such as transcranial magnetic stimulation (TMS), have been explored in various brain disorders, such as schizophrenia [59-61], depression [62], addiction [63,64], and AD [65-67]. Despite many clinical trials being conducted, it remains unclear how neuromodulation approaches can act on neural circuits to result in cellular and molecular responses that modify disease state. To tackle this challenge, preclinical studies in animal models could offer insight into better neuromodulation approaches. Thus, it is crucial to understand how brain state is regulated, how brain state is changed during disease pathogenesis, and how neuromodulation approaches can alter neural activity, resulting in a modification of disease state. 
In this literature review, we focus on AD, the most common form of dementia. Although AD is one of the most intensively studied neurodegenerative diseases [68-78], intervention and treatment options remain limited. In AD, amyloid plaques and tauopathy are major pathological hallmarks, with other pathological features including inflammation and lipid metabolism [68,70,71,73-75,77-80]. Although molecules associated with these features are promising targets for pharmacological treatments [81-85], neuromodulationbased interventions are now being considered, given the multifaceted pathologies of AD.

Abnormalities in EEG patterns have been recognised since as early as the 1930s [30]. Since then, EEG abnormalities have been described in terms of the following three features [31]: (1) slower neural oscillations, (2) decreased complexity of EEG, and (3) reduced degrees of functional connectivity. Hence, these hallmarks of EEG abnormalities can be recognised as either a biomarker of or target for neuromodulation-based intervention. Indeed, accumulating evidence indicates that neuromodulation approaches have the potential to modify Alzheimer's disease states $[47,86]$. In particular, targeting gamma oscillations and slow $(<1 \mathrm{~Hz})$ oscillations has provided encouraging results in AD mouse models [87-92]. Since these oscillations have been well characterised with respect to their induction mechanisms, gamma and slow oscillations would make good targets for neuromodulation-based treatment.

In this review, we first summarise the mechanisms of these two neural oscillations, gamma and slow, followed by a brief overview of the relationship between these oscillations and $\mathrm{AD}$ in both human patients and mouse models. Then, we review recent animal studies that examined the effect of invasive and non-invasive neuromodulation approaches on AD pathology. Finally, we discuss future directions in this field. Readers may also refer to other recent reviews relevant to this field [33,46-49,67,86,93].

\section{Gamma Oscillations and AD}

Jasper and his colleague first described gamma waves [94]. The investigation of gamma (30-90 Hz) oscillations has gained popularity following a series of studies by Freeman [95,96] and by Singer and his colleagues [9]. Gamma oscillations have been observed across many brain regions, not just in the neocortex, but also in the entorhinal cortex [97-99], amygdala [100], hippocampus [101-103], striatum [104,105], olfactory bulb [106,107], basal forebrain [108,109] and developing thalamus [110]. They have been associated with various cognitive functions, including attentional selection [8,111], working memory [12,112], perceptual binding [6,9], and memory encoding [111,113]. Abnormalities in gamma oscillations have links to various neuropsychiatric disorders [34] and neurodegenerative diseases [32]. Here, after describing the induction mechanisms of gamma oscillations, we summarise the relationship between gamma oscillations and AD in both humans and mouse models. Then, we discuss emerging therapeutic approaches based on gamma oscillations.

\subsection{Mechanisms of Gamma Oscillations}

The induction mechanisms of gamma oscillations in cortical circuits have been investigated by a wide range of approaches, including computational models [5,103,114-117], brain slice experiments [118,119] and in vivo optogenetic experiments [120,121]. Computational studies have suggested several mechanisms that are potentially involved in generating gamma oscillations (Figure 2) [5,114,122]. In the interneuron gamma (ING) mechanism (Figure 2A), mutual inhibition between GABAergic neurons is sufficient to generate gamma oscillations. Two distinct regimes can be considered: in the high-firing, noise-free condition, individual GABAergic neurons elicit spikes at around $40 \mathrm{~Hz}$. Mutual inhibition via $\mathrm{GABA}_{\mathrm{A}}$ receptors quickly leads to synchronous firing [103]. In the more realistic, noisy condition, individual GABAergic neurons fire sparsely and stochastically. When the inhibitory feedback is strong enough, gamma oscillations arise. Thus, gamma oscillations are an emerging property of the mutual inhibition network. In both conditions, 
$\mathrm{GABA}_{\mathrm{A}}$ receptor-mediated inhibition plays a role in the generation of gamma oscillations in the absence of excitatory inputs $[103,117]$.
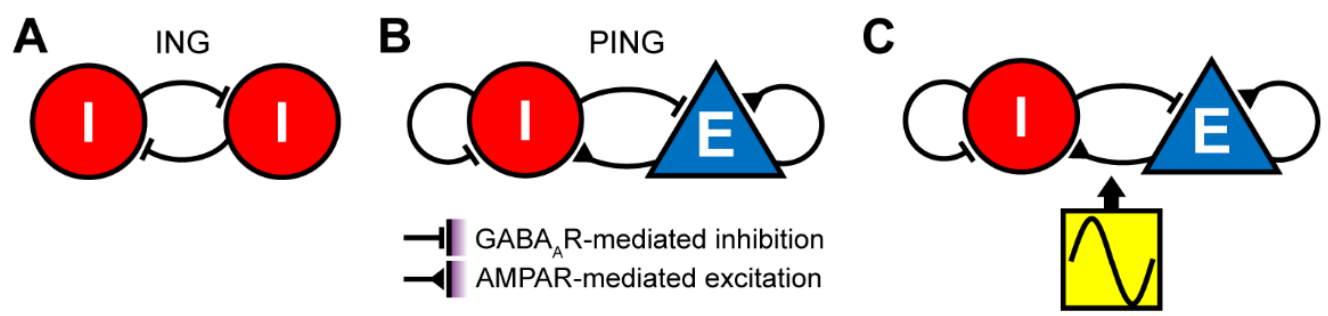

Figure 2. Mechanisms of gamma oscillations. (A) Interneuron gamma (ING) mechanism. Gamma oscillations arise from mutually connected GABAergic neurons. Two regimes can be considered: in one regime, each interneuron fires rhythmically with a frequency determined by the kinetics of the GABAergic feedback ( 40 Hz). In the second regime, although each interneuron sparsely and stochastically fires at an average rate below $40 \mathrm{~Hz}$, recurrent inhibitory interactions lead to gamma oscillations. (B) Pyramidal-interneuron network gamma (PING) mechanism. Pyramidal cells first activate interneurons via AMPA receptors (AMPARs). This leads to recurrent inhibition via $G_{A B A}$ receptors $\left(\mathrm{GABA}_{\mathrm{A}} \mathrm{Rs}\right)$, resulting in rhythmic firing of excitatory and inhibitory populations at the gamma range. (C) Gamma oscillations are inherited by oscillatory activity from upstream areas.

In the pyramidal-interneuron gamma (PING) mechanism (Figure 2B), the alternation between the fast excitation and delayed feedback inhibition can generate gamma oscillations $[5,107,114,122,123]$. The fast excitation is mediated by AMPA receptors, whereas the feedback inhibition is mediated by $\mathrm{GABA}_{\mathrm{A}}$ receptors. The third, simple mechanism is the inheritance of gamma rhythm from upstream areas (Figure 2C) [124]. In this mechanism, the downstream network can reliably and precisely respond to rhythmic inputs from their upstream. In addition to these, other mechanisms can also be taken into consideration, such as neuromodulators [125,126] and pace-making chattering cells [127].

Experimentally, optogenetic activation of cortical parvalbumin-positive (PV+) GABAergic neurons is sufficient to produce gamma oscillations, whereas $\alpha$ CaMKII+ neurons (pyramidal neurons) cannot entrain optogenetic stimulation at the gamma-frequency range [120,121]. Although these results apparently support the ING mechanism, the determination of a precise mechanism is complicated. Although the computational models described above predict how the depolarization of excitatory or inhibitory neurons could affect the oscillations, they do not predict how each network configuration could respond to periodic optogenetic stimulations. Rather, models incorporating physiological data suggested that these optogenetic experiments cannot conclusively distinguish between the ING and PING mechanisms, since the PING model can explain the experimental observations [114]. Thus, further studies with different stimulation protocols are required to determine the mechanisms of gamma oscillations. As gamma oscillations may have therapeutic potential for neurodegenerative diseases, it is important to investigate whether different induction mechanisms of gamma oscillations could lead to distinct molecular and cellular responses and what types of induction mechanisms have beneficial or detrimental effects on AD pathology.

\subsection{Gamma Oscillations and AD in Humans}

While gamma oscillations in human subjects have been assessed by either EEG or magnetoencephalography (MEG), the relationship between AD pathology and changes in gamma oscillations is inconclusive: a number of studies reported a reduction in gamma power or coherence across cortical regions in AD patients $[40,128,129]$, whereas some reported opposite results [39,41,130-132]. This inconsistency may stem from various experimental parameters. For example, gamma oscillations were assessed in an eyeclosed, resting state condition $[40,41,131,133,134]$ or during sensory stimulus presentation $[39,41,129,130,132]$. As expected, cortical regions which showed significant effects also varied depending on conditions and studies. Additionally, while many studies compared 
gamma oscillations between $\mathrm{AD}$ patients and healthy subjects, several studies also compared AD and mild-cognitive impairment (MCI) patients [41,130,131,134]. A consistent approach, recruiting a large number of subjects, would be ideal to address this issue.

A recent study of $>300$ individuals provides valuable insight into changes in gamma oscillations during AD pathogenesis [135]. This study revealed the inverted U-shape relationship between amyloid depositions and gamma power (Figure 3): as the amyloid deposition reaches a supra-threshold level, gamma power increases. On the other hand, as the amyloid deposition increases further to an enhanced pathological state, gamma power decreases. These results imply a compensatory mechanism at an early phase of AD pathogenesis, which may be overwhelmed by a higher amyloid load, leading to a breakdown of neural circuits [135-138]. These results may also be reconciled with the contradictory observations mentioned above, as changes in gamma oscillations may vary depending on the stage of pathogenesis. In the future, it is important to correlate changes in gamma oscillations with AD pathology in large-scale clinical studies. In addition, it is crucial to find out whether animal models can replicate this inverted U-shape relationship to investigate the underlying mechanisms at the molecular, cellular and neural circuit levels.

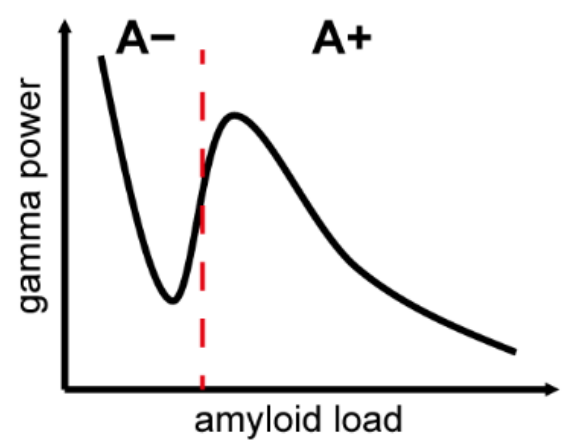

Figure 3. Inverted U-shape relationship between amyloid load and gamma power. This inverted $\mathrm{U}$-shape relationship is evident in the neurodegeneration-positive group assessed by ${ }^{18} \mathrm{~F}$-FDG PET. $\mathrm{A}+$ and $\mathrm{A}-$, amyloid-positive and -negative groups based on ${ }^{18} \mathrm{~F}$-florbetapir PET, respectively. Please note that although these two groups were dichotomized with a threshold (red dotted line), amyloid load is a continuous value. Modified from Gaubert et al. (2019).

\subsection{Gamma Oscillations and AD in Mouse Models}

A reduction in gamma power is consistently observed in various mouse models, including APP-PS1 [139], J20 [140,141], 5xFAD [89], CRND8 [142,143], APOE4 [144,145] and tau models [146] (Table 1). Multiple brain regions have been investigated, such as the hippocampus [89,143,145], entorhinal cortex [139] and prefrontal cortex [140,141]. In the hippocampus, abnormalities in the coupling of gamma oscillations with sharp wave-ripples or theta oscillations have been consistently observed $[89,142,145]$. While these results imply that the overexpression of amyloid- $\beta$ impairs hippocampal ensembles, amyloid precursor protein (APP) also plays a critical role in theta-gamma coupling in the hippocampus, as mice lacking APP exhibit a reduction in theta-gamma coupling without statistically significant changes in gamma and theta power [147].

Additionally, an association between deficits in PV+ neurons and abnormal gamma oscillations has been shown [140,141]. More specifically, this is caused by a reduction in voltage-gated sodium channel subunit Nav1.1 expression in PV+ neurons of J20 mice, with experimental studies illustrating that genetic modifications to increase Nav1.1 expression lead to a restoration of gamma oscillations and a beneficial effect on cognitive decline [141]. Given the mechanisms of gamma oscillations described above (Figure 2), it is important to examine how the deficits in PV+ neurons can affect activity in pyramidal cells and interactions between $\mathrm{PV}+$ and pyramidal neurons. 
Table 1. Gamma oscillations in AD mouse models.

\begin{tabular}{|c|c|c|c|c|c|c|}
\hline Mouse Model & Age (Months) & Sex & Preparation & $\begin{array}{l}\text { Frequency } \\
\text { Band }(\mathrm{Hz})\end{array}$ & Changes in $\gamma$ Oscillations & Reference \\
\hline $\mathrm{APP} / \mathrm{PS} 1$ & $4-5$ & NA & EC slices & $20-60$ & $\begin{array}{c}\text { Reduced } \gamma \text { frequency in LEC } \\
\text { No effect in MEC }\end{array}$ & [139] \\
\hline \multirow{2}{*}{$\mathrm{J} 20$} & $4-7$ & $\mathrm{M} / \mathrm{F}$ & in vivo cEEG & $20-80$ & Reduced $\gamma$ power & [140] \\
\hline & $7-8$ & $\mathrm{M} / \mathrm{F}$ & in vivo cEEG & $30-90$ & Reduced $\gamma$ power & [141] \\
\hline $5 x F A D$ & 3 & M & $\begin{array}{l}\text { in vivo LFP } \\
\text { in CA1 }\end{array}$ & $20-50$ & $\begin{array}{l}\text { Reduced } \gamma \text { power } \\
\text { during SWRs }\end{array}$ & [89] \\
\hline \multirow[t]{2}{*}{ TgCRND8 } & 1 & NA & HC slices & $\begin{array}{c}\theta: 3-12 \\
\text { low } \gamma: 25-85 \\
\text { high } \gamma: 120-250\end{array}$ & $\begin{array}{l}\text { No change in } \gamma \text { power } \\
\text { Disrupted } \theta-\gamma \text { coupling }\end{array}$ & [142] \\
\hline & 1 & M & in vivo HC LFP & $\begin{array}{l}\text { low } \gamma: 25-45 \\
\text { high } \gamma: 60-100\end{array}$ & Reduced $\gamma$ power & [143] \\
\hline \multirow[b]{2}{*}{ APOE4 } & $5-17$ & $\mathrm{~F}$ & in vivo HC LFP & $30-50$ & Reduced $\gamma$ power & {$[144]$} \\
\hline & $4-5$ & $\mathrm{~F}$ & in vivo HC LFP & $30-50$ & $\begin{array}{l}\text { Reduced } \gamma \text { power } \\
\text { during SWRs }\end{array}$ & [145] \\
\hline $\begin{array}{c}\text { 3R tau } \\
\text { overexpression }\end{array}$ & 7 & M & HC slices & $50-90$ & $\begin{array}{l}\text { Reduced } \gamma \text { power and } \\
\text { peak frequency }\end{array}$ & [146] \\
\hline
\end{tabular}

cEEG, cortical EEG. EC, entorhinal cortex. HC, hippocampus. LFP, local field potential. LEC, lateral EC. MEC, medial EC. SWR, sharp wave-ripple.

Intriguingly, a subset of interneurons (such as PV+, somatostatin-positive, and cholecy stokinin-positive GABAergic neurons) are vulnerable to amyloid pathology [140,141,148], whereas pyramidal cells are more vulnerable to tauopathy [149]. These results suggest selective vulnerability depending on $\mathrm{AD}$ pathogenesis and pathologies. As efforts have been made to comprehensively characterise molecular mechanisms of such selective vulnerability in both humans and mouse models [149-153], deficits at the neural circuit level will also become clear in coming years.

Compared to human studies, the following aspects have been less explored in mouse models: firstly, although several studies have investigated multiple age points to show modifications in gamma oscillations during AD pathogenesis [136,145,154,155], none of them have reported the inverted U-shape change, that is, a transient increase in gamma power at an early phase of AD pathogenesis, as reported in a human clinical study (Figure 3). A longitudinal assessment of mouse models correlating with amyloid burden and other pathological features may address this issue. Secondly, commonly used mouse models are familial AD models. Thus, the relation to late-onset $\mathrm{AD}$ (LOAD) remains unclear. A recent effort to develop LOAD mouse models [156] may bridge the gap between human and animal studies. Additionally, the effect of tauopathy in gamma oscillations needs to be explored further. Finally, the electrophysiological approach is markedly different between human and mouse studies. For example, very few studies in mice have assessed sensoryevoked, task event-related or sensory steady-state responses. Additionally, cortex-wide gamma coherence has not been assessed in mice, in contrast to human EEG and MEG studies. Filling these methodological gaps will be crucial in the future.

\subsection{Neuromodulation of Gamma Oscillations for $A D$}

As summarised above, it is clear that a reduction in gamma power is associated with AD pathology, at least in mouse models. Leveraging this knowledge, various invasive and non-invasive neuromodulation approaches have been adopted to modify AD pathology (Table 2) [88-91,157-160]. For example, Tsai and her colleagues have elegantly demonstrated that both invasive and non-invasive gamma stimulations can ameliorate $\mathrm{AD}$ pathology [86,89-91]: optogenetic induction of gamma oscillations in the hippocampus can reduce amyloid load by activating microglia [89]. More surprisingly, non-invasive 
$40 \mathrm{~Hz}$ sensory stimulation (either auditory or visual) has similar effects $[89,90]$. The same approach can also reduce tau phosphorylation and seeding in the T301S model $[89,90]$. These effects are associated with modifications to microglia-associated transcripts, as well as synaptic signaling and plasticity-related proteins $[89,91]$. Although the effect of this non-invasive approach remains to be confirmed in humans, multisensory $40 \mathrm{~Hz}$ stimulation can affect wider brain regions, including hippocampal areas, as well as sensory cortices [90]. Another group showed that optogenetic stimulation of PV+ neurons in the medial septum can induce gamma oscillations in the hippocampus, resulting in an improvement in cognitive function [88]. Although it remains to be determined whether this approach could also reduce amyloid load in the hippocampus, these studies have illustrated the potential for certain induction mechanisms of gamma oscillations to modify AD pathology in a beneficial manner. However, further investigation of these is required before its potential as a non-pharmaceutical therapy is considered.

Table 2. Summary of invasive and non-invasive neuromodulation of gamma oscillations in AD mouse models.

\begin{tabular}{|c|c|c|c|c|c|c|c|c|}
\hline & $\begin{array}{l}\text { Induction } \\
\text { Method }\end{array}$ & $\begin{array}{l}\text { Stimulation } \\
\text { Protocol }\end{array}$ & Duration & Model & Sex & $\begin{array}{c}\text { Age } \\
\text { (Months) }\end{array}$ & Modulated AD Phenotype & Reference \\
\hline \multirow{3}{*}{ 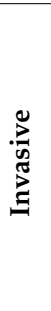 } & \multirow{3}{*}{ Optogenetic } & $\begin{array}{l}1 \mathrm{~ms} \text { pulses, } \\
40 \mathrm{~Hz}, \mathrm{CA} 1\end{array}$ & $1 \mathrm{~h}$ & $\begin{array}{l}\text { 5xFAD::PV-Cre, } \\
\text { AAV5-EF1 } \alpha- \\
\text { DIO-ChR2-eYFP }\end{array}$ & M & 3 & $\begin{array}{c}\text { Reduced } \mathrm{A} \beta \\
\text { Reduced inflammation }\end{array}$ & [89] \\
\hline & & $\begin{array}{l}12 \mathrm{~ms} \text { pulses, } \\
40 \mathrm{~Hz} \text {, Medial } \\
\text { Septum }\end{array}$ & $10 \mathrm{~min}$ & $\begin{array}{l}\text { PVJ20, AAVdj- } \\
\text { EF1 } \alpha \text {-DIO- } \\
\text { ChETA-eYFP }\end{array}$ & $\mathrm{M} / \mathrm{F}$ & NA & Improved spatial memory & [88] \\
\hline & & $\begin{array}{l}40 \mathrm{~Hz} \text {, Basal } \\
\text { Forebrain }\end{array}$ & $\begin{array}{l}1 \mathrm{~h} / \mathrm{d} \text { for } \\
3 \text { days }\end{array}$ & $\begin{array}{l}\text { 5xFAD::PV- } \\
\text { Cre::Ai32 }\end{array}$ & $\mathrm{M} / \mathrm{F}$ & $4-6$ & Increased $A \beta$ & [157] \\
\hline \multirow{12}{*}{ 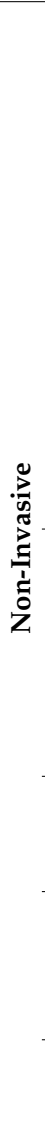 } & \multirow{6}{*}{ Visual } & \multirow{3}{*}{$\begin{array}{c}12.5 \mathrm{~ms} \text { on, } \\
12.5 \mathrm{~ms} \text { off, } \\
40 \mathrm{~Hz} \text { flicker }\end{array}$} & \multirow{3}{*}{$\begin{array}{l}1 \mathrm{~h} / \text { day for } \\
7 \text { days }\end{array}$} & $5 x F A D$ & M & 6 & Reduced $\mathrm{A} \beta$ & \multirow{3}{*}{ [89] } \\
\hline & & & & $\mathrm{APP} / \mathrm{PS} 1$ & $\mathrm{M} / \mathrm{F}$ & 5 & Reduced $A \beta$ & \\
\hline & & & & TauP301S & M & 4 & Reduced tauopathy & \\
\hline & & $40 \mathrm{~Hz}$ flicker & $\begin{array}{l}1 \mathrm{~h} / \text { day for } \\
30 \text { days }\end{array}$ & $\mathrm{APP} / \mathrm{PS} 1$ & $\mathrm{~F}$ & 8 & $\begin{array}{c}\text { Reduced } \mathrm{A} \beta \\
\text { Reduced tauopathy } \\
\text { Increased sleep regulation }\end{array}$ & [160] \\
\hline & & \multirow{2}{*}{$\begin{array}{c}12.5 \mathrm{~ms} \text { on, } \\
12.5 \mathrm{~ms} \text { off, } \\
40 \mathrm{~Hz} \text { flicker }\end{array}$} & $\begin{array}{l}1 \mathrm{~h} / \text { day for } \\
22 \text { days }\end{array}$ & TauP301S & M & $7.5-8$ & $\begin{array}{l}\text { Reduced neuronal damage } \\
\text { Reduced inflammation } \\
\text { Reduced tauopathy } \\
\text { Improved spatial memory }\end{array}$ & \multirow[t]{2}{*}[91]{} \\
\hline & & & $\begin{array}{c}1 \mathrm{~h} / \text { day for } 6 \\
\text { weeks }\end{array}$ & CK-p25 & $\mathrm{M} / \mathrm{F}$ & $6-9$ & $\begin{array}{l}\text { Reduced neuronal damage } \\
\text { Reduced inflammation } \\
\text { Improved spatial memory }\end{array}$ & \\
\hline & \multirow{3}{*}{ Auditory } & \multirow{3}{*}{$\begin{array}{l}1 \mathrm{~ms} 10 \mathrm{kHz} \\
\text { tones, } 40 \mathrm{~Hz} \text {, } \\
60 \mathrm{~dB}\end{array}$} & \multirow{3}{*}{$\begin{array}{l}1 \mathrm{~h} / \text { day for } \\
7 \text { days }\end{array}$} & $5 x F A D$ & NA & 6 & $\begin{array}{c}\text { Reduced A } \beta \\
\text { Reduced inflammation } \\
\text { Improved memory }\end{array}$ & \multirow{4}{*}[90]{} \\
\hline & & & & $\mathrm{APP} / \mathrm{PS} 1$ & NA & $6-9$ & $\begin{array}{c}\text { Reduced A } \beta \\
\text { Reduced inflammation }\end{array}$ & \\
\hline & & & & TauP301S & NA & 2 & Reduced tauopathy & \\
\hline & $\begin{array}{l}\text { Combined } \\
\text { Auditory } \\
\text { and Visual }\end{array}$ & $10 \mathrm{~s}$ on, $10 \mathrm{~s}$ off & $\begin{array}{l}1 \mathrm{~h} / \text { day for } \\
7 \text { days }\end{array}$ & $5 x F A D$ & NA & 6 & $\begin{array}{c}\text { Reduced } \mathrm{A} \beta \\
\text { Reduced inflammation }\end{array}$ & \\
\hline & $\begin{array}{l}\text { Visual and } \\
\text { Exercise }\end{array}$ & $\begin{array}{l}40 \mathrm{~Hz} \text { light } \\
\text { flicker and } \\
30-50 \mathrm{~min} \\
\text { exercise }\end{array}$ & $\begin{array}{l}\text { Daily, } 6 \text { days } \\
\text { a week for } \\
12 \text { weeks }\end{array}$ & $3 \times \mathrm{Tg}$ & M & $12-15$ & $\begin{array}{c}\text { Reduced } \mathrm{A} \beta \\
\text { Reduced tauopathy } \\
\text { Reduced neuronal damage } \\
\text { Improved spatial memory }\end{array}$ & [159] \\
\hline & $\begin{array}{l}\text { Transcranial } \\
\text { Focused } \\
\text { Ultrasound }\end{array}$ & $\begin{array}{c}400 \mu \text { s pulses, } 5 \mathrm{~s} \\
\text { on } 5 \mathrm{~s} \text { off, } 40 \mathrm{~Hz} \text {, } \\
\text { Hippocampus }\end{array}$ & $\begin{array}{l}1 \mathrm{~h} / \text { day for } \\
5 \text { days }\end{array}$ & $5 x F A D$ & M & 6 & $\begin{array}{c}\text { Increased microglia } / \mathrm{A} \beta \\
\text { Co-localisation }\end{array}$ & [158] \\
\hline
\end{tabular}

Interestingly, a recent alternative optogenetic approach to induce cortical gamma oscillations showed opposing effects on AD pathology [157]: although optogenetic activation 
of basal forebrain PV+ neurons could induce cortical gamma oscillations, amyloid load increased in the medial prefrontal cortex and septum. As basal forebrain PV+ neurons preferentially innervate cortical GABAergic neurons [161], the optogenetic activation of basal forebrain PV+ neurons could suppress cortical PV+ neurons, rather than activating them. Thus, the induction mechanism of cortical gamma oscillations in this study differs from that of Iaccarino et al. (2016) [89]. These results suggest that the beneficial effect of gamma oscillations may depend on the induction method, rather than the frequency of local field potentials itself. As there are multiple mechanisms to induce gamma oscillations (Figure 2), it is important to investigate how different approaches can activate different components of neural circuits as well as non-neuronal cells. This type of effort will refine this therapeutic option. As several parameters (duration, frequency, age, etc.) must be explored, real-time monitoring of AD pathology in vivo [162] will accelerate this field.

Regarding clinical applications, since a current major limitation is that most studies have focused on amyloid pathology (Table 2), it is important to investigate how the induction of gamma oscillations affects other pathological features, especially tauopathy $[89,90]$. In addition, because changes in gamma oscillations in humans can vary depending on the stage of $\mathrm{AD}$ pathogenesis [135], it is also critical to determine whether this neuromodulation approach could be beneficial even for patients who exhibit higher gamma power. Again, developing and examining better animal models will benefit this exciting research direction.

\section{Slow Oscillations and AD}

Slow $(<1 \mathrm{~Hz})$ oscillations are another well-characterised type of neural oscillation, since the series of landmark studies by Steriade and colleagues $[20,163,164]$. Slow oscillations are comprised of cycles of global silence (DOWN state) and synchronous firing (UP state) across neuronal populations $[2,163,165-167]$. When they appear during NREM sleep and under anaesthesia, they can predominantly be observed in the cerebral cortex $[2,20,166-170]$, but also in other brain regions, including the thalamus [171,172], thalamic reticular nucleus [173], hippocampus [170], striatum [174,175], brainstem [176] and claustrum [177]. Slow oscillations play a role in sleep-dependent memory consolidation $[26,29,178]$.

The sleep-wake cycle regulates the concentration of amyloid- $\beta$ and tau in the cerebrospinal fluid (CSF) and interstitial fluid (ISF), with a higher level of amyloid- $\beta$ and tau occurring due to prolonged wakefulness or sleep deprivation $[179,180]$. Slow oscillations are also linked to the activity of the glymphatic system, a highly organised CSF transport system, to clear protein waste products including amyloid- $\beta$ [23]. Indeed, abnormalities in slow oscillations have been associated with $\mathrm{AD}[47,49]$. Thus, these results suggest a close relationship between the glymphatic system degradation, sleep disturbance and disease progression in dementias [181].

Here, we summarise how slow oscillations are generated and how the reduction in slow wave activity correlates with AD pathology in human patients and mouse models. Finally, we discuss a therapeutic opportunity based on slow oscillations. Although slow oscillations are closely related to sleep, especially NREM sleep, we focus primarily on the oscillation itself and slow wave activity. Readers may refer to recent comprehensive reviews on sleep and AD elsewhere [46-49,182,183]. Readers can also refer to an up-todate review of the detailed mechanisms of slow oscillations [184]. Although covering the detailed molecular mechanism is beyond the scope of this review article, transcriptomic and synaptic phosphorylation profiles related to sleep-wake cycles have recently been characterised [185,186].

Regarding terminologies, slow oscillations refer to oscillations at less than $1 \mathrm{~Hz}$, whereas delta oscillations refer to oscillations at 1-4 Hz. However, delta oscillations are often described as $0.5-4 \mathrm{~Hz}$ oscillations in literature; hence, they may include slow oscillations. Slow wave activity (SWA) typically refers to spectral power around the 0.5 $-4 \mathrm{~Hz}$ range. SWA is closely associated with sleep homeostasis [187]: it increases 
proportionally to time spent awake and peaks in slow-wave sleep, whereas it decreases as sleep propensity is reduced.

\subsection{Mechanisms of Slow Oscillations}

Earlier studies showed that slow oscillations can be generated in isolated cortical gyrus [188], a cortical slab [169] and cortical slice [189], suggesting that cortical circuits are sufficient for the generation of slow oscillations. Subsequent studies have consistently demonstrated that recurrent excitation of layer (L) 5 pyramidal cells is a source of slow oscillations $[166,168,189,190]$. This notion has been confirmed by computational studies, in which UP and DOWN states can be reproduced by models of neural populations with recurrent excitation and slow adaptation (e.g., activity-dependent $\mathrm{K}^{+}$current or synaptic depression) (Figure 4A) [191-195].
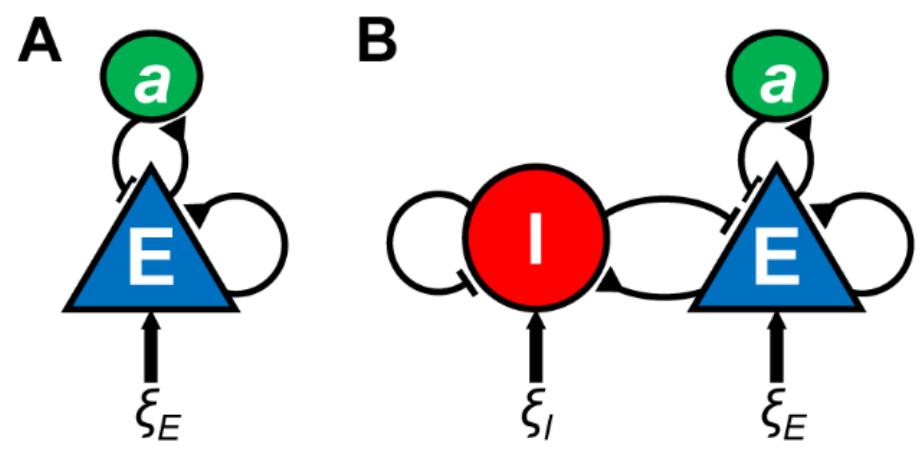

Figure 4. Models of slow oscillations. Two types of neural population (rate) models for UP and DOWN dynamics are illustrated. (A) A neural population model with recurrent excitation, slow adaptive process $a$ and noisy fluctuations $\xi_{E}$. (B) A neural population model with recurrent excitation and inhibition, slow adaptive process and independent noisy inputs. The physiological implementation of the adaptive process can be activity-dependent $\mathrm{K}^{+}$current or synaptic depression.

Multiple receptors and ion channels contribute to shaping UP and DOWN states. For example, both NMDA and non-NMDA receptors are involved in the excitatory drive of UP states [189]. While both excitatory and inhibitory neurons are active during UP states (see below for more details), $\mathrm{GABA}_{\mathrm{A}}$ receptors play a critical role in UP state duration [196]. The termination mechanism of UP states remains to be fully determined, as various processes have been proposed (for a review, see [184]).

Although recurrent excitation of L5 pyramidal cells plays a dominant role in slow oscillations, accumulating evidence has demonstrated a complex picture: while recurrent excitatory activity during UP states is balanced by inhibition [197], two major GABAergic cell classes, PV+ and somatostatin-positive neurons, regulate the transitions of UP and DOWN states [198]. A recent study also showed that deep-layer neurogliaform cells contribute to slow oscillations by preferentially firing during DOWN states [199]. These experimental results may favour the computational models, which implement active contributions from inhibitory neurons to the UP-DOWN dynamics (Figure 4B) [200,201].

With respect to subcortical areas, thalamic neurons play a critical role in the full manifestation of slow oscillations via T-type calcium channels in thalamocortical cells $[171,172]$. Thalamic neurons drive PV+ neurons during DOWN states [202]. PV+ neurons can be also activated by claustral neurons to induce DOWN states across cortical regions [177]. Moreover, it has been suggested that astrocytes play a role in slow oscillations and NREM sleep [203-207]. Thus, the exact mechanisms of slow oscillations remain to be fully determined [208]. While the detailed biophysical models of cortical columns [209,210] could provide valuable insight into the mechanisms of slow oscillations, implementing subcortical inputs and the non-neuronal components are still challenging.

Although slow oscillations can arise from various cortical areas as "slow waves", they often start from the lateral and medial frontal cortical regions and propagate as 
travelling waves to posterior cortical areas in the human brain [211-213]. While cortexwide spontaneous activity can be examined by various means, correlating different signals (e.g., electrical, hemodynamic, intracellular calcium signals) is still an open issue; this would help gain insight into the mechanisms of cortex-wide slow waves.

\subsection{Slow Oscillations and AD in Humans}

Sleep disturbance is a common symptom of AD pathogenesis, with sleep fragmentation, increased nocturnal activity and excessive daytime napping contributing to the disruptions to daily life $[46,214-220]$. Thus, it is not surprising to see the robust association between abnormalities in slow-wave sleep and AD pathology in humans [46,221-226]. Additionally, earlier studies in the 1980s and 1990s demonstrated an association between abnormalities in slow wave activity and AD pathology, including cognitive functions [227-229]. Specifically, studies show that impairments in slow-wave sleep are associated with impaired cognition. In recent decades, it has become evident that these associations are underpinned by structural changes and AD pathology in the brain: age-related prefrontal atrophy is associated with reduced slow-wave activity during NREM sleep [230]. Additionally, a bi-directional relationship between slow-wave sleep and AD pathology exists, as slow-wave activity during NREM sleep decreases as amyloid- $\beta$ deposition and tau accumulation increase [231,232]. The reduction in slow-wave activity is also associated with the impairment in sleep-dependent memory consolidation [231]. Thus, changes in slow oscillations are a robust biomarker of AD pathogenesis in humans although underlying cellular and circuit mechanisms remain unclear.

\subsection{Slow Oscillations and AD in Mouse Models}

The sleep-wake cycle has been examined across different pathological stages in various mouse models, including 3xTg-AD [233,234], APP/PS1 [234,235], Tg2576 [234,236], P301S Tau [237], rTG4510 [238], PLB1 Triple [239], and PLB2tau [240] models (Table 3). Slow (<1 Hz) oscillations have been analysed together with delta oscillations (1-4 Hz), which can be used to determine NREM sleep. In several AD mouse models, NREM sleep is reduced and fragmented $[233,234,237,238]$, which implies that changes also occur in the patterns of slow oscillations. It has been suggested that the reduction in GABAergic tone impairs longrange synchronous firing in an amyloid mouse model [92]. Intriguingly, P301S Tau model exhibited the inverted U-shape profile at the delta frequency, meaning that delta power increases at an early disease stage, whereas it decreases at a later stage [237]. Longitudinal studies in AD mouse models may provide valuable insight into the mechanisms of agerelated changes in slow oscillations.

\subsection{Neuromodulation of Slow Oscillations for $A D$}

Pharmacological and optogenetic intervention approaches can modify abnormalities in slow oscillations, hence the AD disease state in mouse models (Table 4) [87,92,241,242]. For example, a breakdown of long-range coherence of slow oscillations in an AD mouse model can be rescued by enhancing GABAergic inhibition with a $\mathrm{GABA}_{\mathrm{A}}$ receptor agonist [92]. This is consistent with the notion that aberrant somatic GABAergic tone plays a critical role in the hyperactivity of cortical neurons [140,243]. Kastanenka and his colleagues demonstrated frequency-specific effects of optogenetically induced cortical slow oscillations on AD pathology $[87,241]$ : slow-wave-specific $0.6 \mathrm{~Hz}$ optogenetic stimulation of $\alpha \mathrm{CaMKII}+$ neurons in the anterior cortical area can reduce amyloid- $\beta$ and increase $\mathrm{GABA}_{\mathrm{A}}$ and $\mathrm{GABA}_{\mathrm{B}}$ receptor expression. On the other hand, $1.2 \mathrm{~Hz}$ stimulation, a slight offset from a slow-wave-specific frequency band, shows an opposing effect without altering $\mathrm{GABA}_{\mathrm{A}}$ and $\mathrm{GABA}_{\mathrm{B}}$ receptor expression. These results imply that increasing inhibitory tone may play a role in reducing amyloid burden. One potential caveat is that, because increased and decreased firing rate can also modify AD pathology [244-247], optogenetic stimulation at higher frequencies may also induce a higher firing rate, leading to the promotion of amyloid deposition. Future studies are needed to determine whether and how the temporal 
structure of neural population activity, rather than simple firing rates, can modify AD pathology. Additionally, although abnormalities in slow and delta oscillations have been reported in tau models (Table 3), it remains to be explored whether artificial manipulations of slow oscillations can modify tauopathy as well as other pathological features.

Table 3. Slow and delta oscillations in AD mouse models.

\begin{tabular}{|c|c|c|c|c|c|}
\hline Mouse Model & Age (Months) & Sex & $\begin{array}{l}\text { Frequency } \\
\text { Band (Hz) }\end{array}$ & Changes in Oscillations & Reference \\
\hline $3 x T g-A D$ & 7,20 & $\mathrm{M} / \mathrm{F}$ & $<1$ & $\begin{array}{l}\text { Increased frequency at } 7 \text { months } \\
\text { Decreased frequency at } 20 \text { months } \\
\text { More irregular at } 20 \text { months }\end{array}$ & [233] \\
\hline $3 \times T g-A D$ & 18 & $\mathrm{M} / \mathrm{F}$ & $0.1-4$ & No change & \multirow{3}{*}{ [234] } \\
\hline $\mathrm{APP} / \mathrm{PS} 1$ & $8-10$ & $\mathrm{M} / \mathrm{F}$ & $0.1-4$ & Decreased power during NREM & \\
\hline $\operatorname{Tg} 2576$ & 12 & $\mathrm{M} / \mathrm{F}$ & $0.1-4$ & Decreased power during $\mathrm{W}$ & \\
\hline $\operatorname{Tg} 2576$ & $2,6,12$ & NA & $0.5-4$ & Decreased power during NREM at 6-12 months & {$[236]$} \\
\hline $\mathrm{APP} / \mathrm{PS} 1$ & $3,6,9$ & NA & $>1$ & Shorter NREM at 9 months & [235] \\
\hline P301S & $3-12$ & M & $1-4$ & $\begin{array}{c}\text { Increased power during NREM at 6-9 months } \\
\text { Decreased power during W and NREM at } \\
11 \text { months }\end{array}$ & [237] \\
\hline rTg4510 & $5-10$ & M & $0.1-4$ & Decreased power during NREM from 6 months & [238] \\
\hline PLB1triple & $5-21$ & $\mathrm{M} / \mathrm{F}$ & $0.5-5$ & $\begin{array}{l}\text { Decreased power during REM at } 9 \text { months } \\
\text { Decreased power during } W \text { at } 21 \text { months }\end{array}$ & [239] \\
\hline PLB2tau & 6 & $\mathrm{~F}$ & $1.5-5$ & $\begin{array}{l}\text { Increased power during REM } \\
\text { Decreased power during NREM }\end{array}$ & [240] \\
\hline
\end{tabular}

REM, rapid eye movement sleep. NREM, non-REM sleep. W, wakefulness.

Table 4. Summary of invasive and non-invasive neuromodulation of slow oscillations in AD mouse models.

\begin{tabular}{|c|c|c|c|c|c|c|c|c|}
\hline & $\begin{array}{l}\text { Induction } \\
\text { Method }\end{array}$ & Protocol & Duration & Model & Sex & $\begin{array}{c}\text { Age } \\
\text { (Months) }\end{array}$ & $\begin{array}{l}\text { Modulated AD } \\
\text { Phenotype }\end{array}$ & Reference \\
\hline \multirow{2}{*}{ 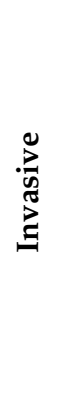 } & \multirow[b]{2}{*}{ Optogenetic } & $\begin{array}{c}400 \mathrm{~ms} \text { pulses, } \\
0.6 \mathrm{~Hz} \text {, Anterior } \\
\text { Cortex }\end{array}$ & $\begin{array}{l}24 \mathrm{~h} / \text { day } \\
\text { for } 1 \text { month }\end{array}$ & $\begin{array}{c}\text { APP/PS1, } \\
\text { AAV5-CamKII } \alpha- \\
\text { hChR2(H134R)- } \\
\text { mCherry }\end{array}$ & $\mathrm{M} / \mathrm{F}$ & $4-7$ & $\begin{array}{c}\text { Reduced A } \beta \\
\text { Reduced calcium } \\
\text { overload } \\
\text { Restored GABA levels }\end{array}$ & [87] \\
\hline & & $\begin{array}{c}400 \mathrm{~ms} \text { pulses, } \\
1.2 \mathrm{~Hz} \text {, Anterior } \\
\text { Cortex }\end{array}$ & $\begin{array}{l}24 \mathrm{~h} / \text { day } \\
\text { for } 1 \text { month }\end{array}$ & $\begin{array}{c}\text { APP/PS1, } \\
\text { AAV5-CamKII } \alpha- \\
\text { hChR2(H134R)- } \\
\text { mCherry }\end{array}$ & $\mathrm{M} / \mathrm{F}$ & $3-9$ & $\begin{array}{c}\text { Increased A } \beta \\
\text { Increased calcium } \\
\text { overload } \\
\text { Decreased spine } \\
\text { densityNo change in } \\
\text { GABA levels }\end{array}$ & [241] \\
\hline \multirow{2}{*}{ 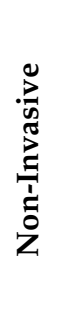 } & $\begin{array}{l}\text { BACE } \\
\text { Inhibitor } \\
\text { (oral) }\end{array}$ & $\begin{array}{l}\text { Administration } \\
\text { of } 0.25 \mathrm{~g} / \mathrm{kg} \\
\mathrm{NB}-360 \mathrm{in} \\
\text { food pellets }\end{array}$ & $\begin{array}{l}6 \text { weeks } \\
\text { ad lib }\end{array}$ & APP23xPS45 & $\mathrm{F}$ & $6-8$ & $\begin{array}{c}\text { Reduced A } \beta \\
\text { Reduced calcium } \\
\text { overload } \\
\text { Improved spatial } \\
\text { memory }\end{array}$ & [242] \\
\hline & $\begin{array}{l}\text { GABA-A } \\
\text { Agonist } \\
\text { (i.p.) }\end{array}$ & $\begin{array}{l}\text { Administration } \\
\text { of } 0.05 \mathrm{mg} / \mathrm{kg} \\
\text { clonazepam }\end{array}$ & $\begin{array}{l}\text { Once/day } \\
\text { for } 5 \text { days }\end{array}$ & APP23xPS45 & $\mathrm{M} / \mathrm{F}$ & $6-8$ & $\begin{array}{l}\text { Improved spatial } \\
\text { memory }\end{array}$ & [92] \\
\hline
\end{tabular}

Nevertheless, these studies suggest that pharmacological and non-pharmacological interventions for slow oscillations have therapeutic potential for AD. Indeed, accumulating evidence shows bidirectional relationships between sleep and AD pathogenesis $[48,248]$. It is important to investigate whether artificially enhanced slow oscillations can also 
trigger other non-neuronal events, such as glymphatic waste clearance, which can be seen in natural slow-wave sleep and even under anaesthesia [23,249]. As discussed above, because multiple components contribute to slow oscillations, various approaches could be explored to modify these and, hence, AD pathology. It is by taking advantage of these various approaches for the neuromodulation of slow oscillations that evidence for potential different modes of action on AD pathology will be unearthed.

\section{Conclusions and Future Directions}

By focusing on gamma and slow oscillations, we summarised how these oscillations can change during AD pathogenesis in both humans and mouse models. We also reviewed emerging invasive and non-invasive neuromodulation approaches to modify AD pathology in mouse models based on gamma and slow oscillations. Although further studies are essential to uncover the underlying mechanisms before clinical applications, these neuromodulation-based interventions are promising frontiers for AD and beyond.

To further explore this emerging field, the following four areas are important for investigation. Firstly, it is essential to comprehensively characterise electrophysiological biomarkers in AD animal models, with respect to neural oscillations. As well as offering potential biomarkers for early diagnosis, this will aid in the understanding of neural oscillations in AD and abnormalities throughout its progression. As we discussed above, although reduced gamma power has consistently been reported in mouse models (Table 1), the available evidence in human patients is conflicting [39-41,128-132]. The gap between mouse models and humans may be due to discrepancies in methodologies between studies, a lack of proper longitudinal studies in mouse models, or the limitations of animal models [250]. Since better mouse models which reflect human pathological features are under development [156], it will become important to conduct detailed in vivo electrophysiological investigations correlating with various molecular and cellular AD pathologies-not just amyloid pathology, but also tauopathy and other pathological features.

Secondly, it is worth exploring other brain states, not just gamma and slow oscillations, because a wide range of neural oscillations or events have been studied in general neuroscience $[1,13,33,251]$. With respect to sleep, the reduction in REM sleep duration is an early biomarker during AD pathogenesis [221,227,228,252]. During REM sleep, hippocampal theta rhythms and ponto-geniculo-occipital (PGO) waves are prominent electrophysiological markers $[14,21,253,254]$. Intriguingly, PGO waves and theta rhythms are temporally coupled across animal models [21,255-257]. Therefore, it is interesting to investigate how this functional coupling between several sleep-related neural events is affected during AD pathogenesis. PGO waves are originated from mesopontine cholinergic areas $[17,19,258]$ and the neurodegeneration of mesopontine cholinergic neurons has been associated with AD [259,260], as well as Lewy body dementia [261]. Additionally, abnormalities in sleep spindles and sharp wave-ripples during NREM sleep have also been associated with AD $[16,49,252,262]$. Therefore, these sleep-related neural oscillations may be alternative targets for non-pharmacological interventions.

Thirdly, the means of neuromodulation needs to be explored further. Although optogenetic approaches can achieve cell type-specific manipulations with a high spatiotemporal resolution, non-invasive approaches are ideal for clinical applications. A chemogenetic approach, along with a detailed characterization of brain state, could be a promising direction, since a recent study demonstrated that the chemogenetic attenuation of hyperactivity in the entorhinal cortex can ameliorate AD pathology, including the spread of pathological tau [245]. At present, repetitive transcranial magnetic stimulation (rTMS) and transcranial direct or alternating current stimulation (tDCS/ACS) have shown promising results $[65,66]$. In addition to these brain stimulation methods, sensory stimulation is also an attractive approach to modulate gamma oscillations across brain regions [86,89,90]. Several neural oscillations or neural events during sleep are also known to be induced or modulated by sensory inputs [263-265]: for example, PGO waves during REM sleep can be triggered by sounds [265]. In addition, slow oscillations can be modulated by sounds to promote 
memory consolidation [263]. Thus, neuromodulations based on auditory stimulus during sleep may be an attractive option.

Finally, the most important research direction is to uncover the mechanisms of how the manipulation of neural oscillations can modify pathological features across multiple spatial levels, from molecular to neural circuit levels. Supposing that neurons are a key driver for a certain neural oscillation, how can subsequent molecular responses trigger non-neuronal events, such as microglial and astrocytic activation and the modification of neurovascular coupling? In addition, neural oscillations are typically induced by multiple neural circuit motifs $[5,208,266]$. A fundamental issue is to uncover the direct link among electrophysiological signatures, cell-type-specific neuronal activity, non-neuronal activity and molecular responses. Given the complexity of such interactions over multiple spatiotemporal scales, computational approaches will play a crucial role in better understanding the effects of neuromodulation approaches on AD pathology. Thus, we predict that integrative, systems-level approaches will become increasingly important in the coming years.

In conclusion, bi-directional relationships between AD pathology and brain states have become evident. While gamma oscillations and slow oscillations are promising targets, many issues remain to be explored. For future clinical applications, it is crucial to establish a causal relationship between AD pathology and neuromodulations at various levels, from molecules to neural circuits.

Author Contributions: N.B. and S.S. wrote the manuscript with the input from A.S. All authors have read and agreed to the published version of the manuscript.

Funding: This work was supported by Horizon2020-RIA (DEEPER, 101016787) and MRC (MR/V033964/1) to SS.

Institutional Review Board Statement: Not applicable.

Informed Consent Statement: Not applicable.

Data Availability Statement: All data are included in this published article as figures and tables.

Conflicts of Interest: The authors declare no conflict of interest.

\section{References}

1. Buzsáki, G.; Draguhn, A. Neuronal Oscillations in Cortical Networks. Science 2004, 304, 1926-1929. [CrossRef]

2. Harris, K.; Thiele, A. Cortical state and attention. Nat. Rev. Neurosci. 2011, 12, 509-523. [CrossRef]

3. Buzsáki, G.; Logothetis, N.; Singer, W. Scaling Brain Size, Keeping Timing: Evolutionary Preservation of Brain Rhythms. Neuron 2013, 80, 751-764. [CrossRef]

4. Berger, H. Über das Elektrenkephalogramm des Menschen. Eur. Arch. Psychiatry Clin. Neurosci. 1929, 87, 527-570. [CrossRef]

5. Buzsáki, G.; Wang, X.-J. Mechanisms of Gamma Oscillations. Annu. Rev. Neurosci. 2012, 35, 203-225. [CrossRef]

6. Engel, A.K.; Fries, P.; Singer, W. Dynamic predictions: Oscillations and synchrony in top-down processing. Nat. Rev. Neurosci. 2001, 2, 704-716. [CrossRef]

7. Fries, P. Neuronal Gamma-Band Synchronization as a Fundamental Process in Cortical Computation. Annu. Rev. Neurosci. 2009, 32, 209-224. [CrossRef]

8. Fries, P. Rhythms for Cognition: Communication through Coherence. Neuron 2015, 88, 220-235. [CrossRef]

9. Singer, W.; Gray, C.M. Visual Feature Integration and the Temporal Correlation Hypothesis. Annu. Rev. Neurosci. 1995, 18, 555-586. [CrossRef]

10. Varela, F.; Lachaux, J.-P.; Rodriguez, E.; Martinerie, J. The brainweb: Phase synchronization and large-scale integration. Nat. Rev. Neurosci. 2001, 2, 229-239. [CrossRef]

11. Wang, X.-J. Neurophysiological and Computational Principles of Cortical Rhythms in Cognition. Physiol. Rev. 2010, 90, 1195-1268. [CrossRef]

12. Miller, E.K.; Lundqvist, M.; Bastos, A.M. Working Memory 2.0. Neuron 2018, 100, 463-475. [CrossRef] [PubMed]

13. Adamantidis, A.R.; Herrera, C.G.; Gent, T.C. Oscillating circuitries in the sleeping brain. Nat. Rev. Neurosci. 2019, 20, 746-762. [CrossRef]

14. Brown, R.; Basheer, R.; McKenna, J.; Strecker, R.E.; McCarley, R. Control of Sleep and Wakefulness. Physiol. Rev. 2012, 92, 1087-1187. [CrossRef] [PubMed]

15. Buzsáki, G. Theta Oscillations in the Hippocampus. Neuron 2002, 33, 325-340. [CrossRef] 
16. Buzsáki, G. Hippocampal sharp wave-ripple: A cognitive biomarker for episodic memory and planning. Hippocampus 2015, 25, 1073-1188. [CrossRef] [PubMed]

17. Callaway, C.; Lydic, R.; Baghdoyan, H.A.; Hobson, J.A. Pontogeniculooccipital waves: Spontaneous visual system activity during rapid eye movement sleep. Cell. Mol. Neurobiol. 1987, 7, 105-149. [CrossRef]

18. Colgin, L.L. Rhythms of the hippocampal network. Nat. Rev. Neurosci. 2016, 17, 239-249. [CrossRef]

19. Datta, S. Cellular basis of pontine ponto-geniculo-occipital wave generation and modulation. Cell. Mol. Neurobiol. 1997, 17, 341-365. [CrossRef]

20. Steriade, M.; Nunez, A.; Amzica, F. A novel slow ( $<1 \mathrm{~Hz})$ oscillation of neocortical neurons in vivo: Depolarizing and hyperpolarizing components. J. Neurosci. 1993, 13, 3252-3265. [CrossRef] [PubMed]

21. Tsunematsu, T.; Patel, A.A.; Onken, A.; Sakata, S. State-dependent brainstem ensemble dynamics and their interactions with hippocampus across sleep states. eLife 2020, 9, 9. [CrossRef]

22. Mestre, H.; Mori, Y.; Nedergaard, M. The Brain's Glymphatic System: Current Controversies. Trends Neurosci. 2020, 43, 458-466. [CrossRef] [PubMed]

23. Xie, L.; Kang, H.; Xu, Q.; Chen, M.J.; Liao, Y.; Thiyagarajan, M.; O’Donnell, J.; Christensen, D.J.; Nicholson, C.; Iliff, J.J.; et al. Sleep Drives Metabolite Clearance from the Adult Brain. Science 2013, 342, 373-377. [CrossRef]

24. Buzsáki, G. Two-stage model of memory trace formation: A role for "noisy" brain states. Neuroscience 1989, 31, 551-570. [CrossRef]

25. Fernández-Ruiz, A.; Oliva, A.; De Oliveira, E.F.; Rocha-Almeida, F.; Tingley, D.; Buzsáki, G. Long-duration hippocampal sharp wave ripples improve memory. Science 2019, 364, 1082-1086. [CrossRef] [PubMed]

26. Kim, J.; Gulati, T.; Ganguly, K. Competing Roles of Slow Oscillations and Delta Waves in Memory Consolidation versus Forgetting. Cell 2019, 179, 514-526. [CrossRef]

27. Born, J.; Rasch, B.; Gais, S. Sleep to Remember. Neuroscience 2006, 12, 410-424. [CrossRef] [PubMed]

28. Stickgold, R.; Hobson, J.A.; Fosse, R.; Fosse, M. Sleep, Learning, and Dreams: Off-line Memory Reprocessing. Science 2001, 294, 1052-1057. [CrossRef]

29. Todorova, R.; Zugaro, M. Isolated cortical computations during delta waves support memory consolidation. Science 2019, 366, 377-381. [CrossRef]

30. Berger, H. Über das Elektrenkephalogramm des Menschen. Dritte Mitteilung. Eur. Arch. Psychiatry Clin. Neurosci. 1931, 94, 16-60. [CrossRef]

31. Jeong, J. EEG dynamics in patients with Alzheimer's disease. Clin. Neurophysiol. 2004, 115, 1490-1505. [CrossRef] [PubMed]

32. Mably, A.J.; Colgin, L.L. Gamma oscillations in cognitive disorders. Curr. Opin. Neurobiol. 2018, 52, 182-187. [CrossRef] [PubMed]

33. Takeuchi, Y.; Berényi, A. Oscillotherapeutics-Time-targeted interventions in epilepsy and beyond. Neurosci. Res. 2020, 152, 87-107. [CrossRef] [PubMed]

34. Uhlhaas, P.J.; Singer, W. Abnormal neural oscillations and synchrony in schizophrenia. Nat. Rev. Neurosci. 2010, 11, 100-113. [CrossRef]

35. Rojas, D.C.; Wilson, L.B. $\gamma$-band abnormalities as markers of autism spectrum disorders. Biomark. Med. 2014, 8, 353-368. [CrossRef]

36. Simon, D.M.; Wallace, M.T. Dysfunction of sensory oscillations in Autism Spectrum Disorder. Neurosci. Biobehav. Rev. 2016, 68, 848-861. [CrossRef] [PubMed]

37. Baskaran, A.; Milev, R.; McIntyre, R.S. The neurobiology of the EEG biomarker as a predictor of treatment response in depression. Neuropharmacology 2012, 63, 507-513. [CrossRef] [PubMed]

38. Fitzgerald, P.J.; Watson, B.O. Gamma oscillations as a biomarker for major depression: An emerging topic. Transl. Psychiatry 2018, 8, 1-7. [CrossRef]

39. Osipova, D.; Pekkonen, E.; Ahveninen, J. Enhanced magnetic auditory steady-state response in early Alzheimer's disease. Clin. Neurophysiol. 2006, 117, 1990-1995. [CrossRef]

40. Stam, C.J.; van Cappellen van Walsum, A.M.; Pijnenburg, Y.A.L.; Berendse, H.W.; de Munck, J.C.; Scheltens, P.; Van Dijk, B.W. Generalized Synchronization of MEG Recordings in Alzheimer's Disease: Evidence for Involvement of the Gamma Band. J. Clin. Neurophysiol. 2002, 19, 562-574. [CrossRef] [PubMed]

41. Van Deursen, J.A.; Vuurman, E.F.P.M.; Verhey, F.R.J.; Van Kranen-Mastenbroek, V.H.J.M.; Riedel, W. Increased EEG gamma band activity in Alzheimer's disease and mild cognitive impairment. J. Neural Transm. 2008, 115, 1301-1311. [CrossRef] [PubMed]

42. Ford, D.E.; Kamerow, D.B. Epidemiologic study of sleep disturbances and psychiatric disorders. An opportunity for prevention? JAMA 1989, 262, 1479-1484. [CrossRef] [PubMed]

43. Kaskie, E.R.; Graziano, B.; Ferrarelli, F. Schizophrenia and sleep disorders: Links, risks, and management challenges. Nat. Sci. Sleep 2017, 9, 227-239. [CrossRef] [PubMed]

44. Manoach, D.S.; Stickgold, R. Abnormal Sleep Spindles, Memory Consolidation, and Schizophrenia. Annu. Rev. Clin. Psychol. 2019, 15, 451-479. [CrossRef] [PubMed]

45. Dolsen, M.R.; Harvey, A.G. Life-time history of insomnia and hypersomnia symptoms as correlates of alcohol, cocaine and heroin use and relapse among adults seeking substance use treatment in the United States from 1991 to 1994. Addiction 2017, 112, 1104-1111. [CrossRef]

46. Kent, B.A.; Feldman, H.H.; Nygaard, H.B. Sleep and its regulation: An emerging pathogenic and treatment frontier in Alzheimer's disease. Prog. Neurobiol. 2021, 197, 101902. [CrossRef] [PubMed] 
47. Lee, Y.F.; Gerashchenko, D.; Timofeev, I.; Bacskai, B.J.; Kastanenka, K.V. Slow Wave Sleep Is a Promising Intervention Target for Alzheimer's Disease. Front. Neurosci. 2020, 14, 705. [CrossRef]

48. Wang, C.; Holtzman, D.M. Bidirectional relationship between sleep and Alzheimer's disease: Role of amyloid, tau, and other factors. Neuropsychopharmacology 2020, 45, 104-120. [CrossRef]

49. Mander, B.A. Local Sleep and Alzheimer's Disease Pathophysiology. Front. Neurosci. 2020, 14, 525970. [CrossRef]

50. Krames, E.; Peckham, P.H.; Rezai, A. Neuromodulation: Comprehensive Textbook of Principles, Technologies, and Terapies, 2nd ed.; Academic Press: Cambridge, MA, USA, 2018.

51. Poewe, W.; Seppi, K.; Tanner, C.M.; Halliday, G.M.; Brundin, P.; Volkmann, J.; Schrag, A.E.; Lang, A.E. Parkinson disease. Nat. Rev. Dis. Prim. 2017, 3, 17013. [CrossRef] [PubMed]

52. Benabid, A.; Pollak, P.; Hoffmann, D.; Gervason, C.; Hommel, M.; Perret, J.; De Rougemont, J.; Gao, D. Long-term suppression of tremor by chronic stimulation of the ventral intermediate thalamic nucleus. Lancet 1991, 337, 403-406. [CrossRef]

53. Scangos, K.W.; Makhoul, G.S.; Sugrue, L.P.; Chang, E.F.; Krystal, A.D. State-dependent responses to intracranial brain stimulation in a patient with depression. Nat. Med. 2021, 27, 229-231. [CrossRef]

54. Mayberg, H.S.; Lozano, A.M.; Voon, V.; McNeely, H.E.; Seminowicz, D.; Hamani, C.; Schwalb, J.M.; Kennedy, S. Deep Brain Stimulation for Treatment-Resistant Depression. Neuron 2005, 45, 651-660. [CrossRef] [PubMed]

55. Grover, S.; Nguyen, J.A.; Viswanathan, V.; Reinhart, R.M.G. High-frequency neuromodulation improves obsessive-compulsive behavior. Nat. Med. 2021, 27, 232-238. [CrossRef] [PubMed]

56. Greenberg, B.D.; Malone, D.A.; Friehs, G.M.; Rezai, A.R.; Kubu, C.S.; Malloy, P.F.; Salloway, S.P.; Okun, M.; Goodman, W.K.; Rasmussen, S.A. Three-Year Outcomes in Deep Brain Stimulation for Highly Resistant Obsessive-Compulsive Disorder. Neuropsychopharmacology 2006, 31, 2384-2393. [CrossRef]

57. Mirzadeh, Z.; Bari, A.; Lozano, A.M. The rationale for deep brain stimulation in Alzheimer's disease. J. Neural Transm. 2015, 123, 775-783. [CrossRef]

58. Kuhn, J.; Hardenacke, K.; Lenartz, D.; Gruendler, T.; Ullsperger, M.; Bartsch, C.; Mai, J.K.; Zilles, K.; Bauer, A.; Matusch, A.; et al. Deep brain stimulation of the nucleus basalis of Meynert in Alzheimer's dementia. Mol. Psychiatry 2014, 20, 353-360. [CrossRef] [PubMed]

59. Ahn, S.; Mellin, J.M.; Alagapan, S.; Alexander, M.L.; Gilmore, J.H.; Jarskog, L.F.; Fröhlich, F. Targeting reduced neural oscillations in patients with schizophrenia by transcranial alternating current stimulation. NeuroImage 2019, 186, 126-136. [CrossRef]

60. Brunelin, J.; Mondino, M.; Gassab, L.; Haesebaert, F.; Gaha, L.; Suaud-Chagny, M.-F.; Saoud, M.; Mechri, A.; Poulet, E. Examining Transcranial Direct-Current Stimulation (tDCS) as a Treatment for Hallucinations in Schizophrenia. Am. J. Psychiatry 2012, 169, 719-724. [CrossRef]

61. Farzan, F.; Barr, M.S.; Sun, Y.; Fitzgerald, P.B.; Daskalakis, Z.J. Transcranial magnetic stimulation on the modulation of gamma oscillations in schizophrenia. Ann. New York Acad. Sci. 2012, 1265, 25-35. [CrossRef] [PubMed]

62. Fox, M.D.; Buckner, R.L.; White, M.P.; Greicius, M.D.; Pascual-Leone, A. Efficacy of Transcranial Magnetic Stimulation Targets for Depression Is Related to Intrinsic Functional Connectivity with the Subgenual Cingulate. Biol. Psychiatry 2012, 72, 595-603. [CrossRef]

63. Terraneo, A.; Leggio, L.; Saladini, M.; Ermani, M.; Bonci, A.; Gallimberti, L. Transcranial magnetic stimulation of dorsolateral prefrontal cortex reduces cocaine use: A pilot study. Eur. Neuropsychopharmacol. 2016, 26, 37-44. [CrossRef] [PubMed]

64. Diana, M.; Raij, T.; Melis, M.; Nummenmaa, A.; Leggio, L.; Bonci, A. Rehabilitating the addicted brain with transcranial magnetic stimulation. Nat. Rev. Neurosci. 2017, 18, 685-693. [CrossRef] [PubMed]

65. Holczer, A.; Németh, V.L.; Vékony, T.; Vécsei, L.; Klivenyi, P.; Must, A. Non-invasive Brain Stimulation in Alzheimer's Disease and Mild Cognitive Impairment-A State-of-the-Art Review on Methodological Characteristics and Stimulation Parameters. Front. Hum. Neurosci. 2020, 14, 179. [CrossRef]

66. Freitas, C.; Mondragón-Llorca, H.; Pascual-Leone, A. Noninvasive brain stimulation in Alzheimer's disease: Systematic review and perspectives for the future. Exp. Gerontol. 2011, 46, 611-627. [CrossRef] [PubMed]

67. Bréchet, L.; Michel, C.M.; Schacter, D.L.; Pascual-Leone, A. Improving autobiographical memory in Alzheimer's disease by transcranial alternating current stimulation. Curr. Opin. Behav. Sci. 2021, 40, 64-71. [CrossRef]

68. Hardy, J.; Selkoe, D.J. The amyloid hypothesis of Alzheimer's disease: Progress and problems on the road to therapeutics. Science 2002, 297, 353-356. [CrossRef]

69. Henstridge, C.M.; Hyman, B.T.; Spires-Jones, T.L. Beyond the neuron-cellular interactions early in Alzheimer disease pathogenesis. Nat. Rev. Neurosci. 2019, 20, 94-108. [CrossRef]

70. Herrup, K. The case for rejecting the amyloid cascade hypothesis. Nat. Neurosci. 2015, 18, 794-799. [CrossRef]

71. Long, J.; Holtzman, D.M. Alzheimer Disease: An Update on Pathobiology and Treatment Strategies. Cell 2019, 179, 312-339. [CrossRef]

72. Musiek, E.; Holtzman, D.M. Three dimensions of the amyloid hypothesis: Time, space and 'wingmen'. Nat. Neurosci. 2015, 18, 800-806. [CrossRef]

73. Ballatore, C.; Lee, V.M.-Y.; Trojanowski, J.Q. Tau-mediated neurodegeneration in Alzheimer's disease and related disorders. Nat. Rev. Neurosci. 2007, 8, 663-672. [CrossRef]

74. Butterfield, D.A.; Halliwell, B. Oxidative stress, dysfunctional glucose metabolism and Alzheimer disease. Nat. Rev. Neurosci. 2019, 20, 148-160. [CrossRef] 
75. Hickman, S.; Izzy, S.; Sen, P.; Morsett, L.; El Khoury, J. Microglia in neurodegeneration. Nat. Neurosci. 2018, 21, 1359-1369. [CrossRef]

76. Lee, V.M.-Y.; Goedert, M.; Trojanowski, J.Q. Neurodegenerative Tauopathies. Annu. Rev. Neurosci. 2001, 24, 1121-1159. [CrossRef] [PubMed]

77. Saez-Atienzar, S.; Masliah, E. Cellular senescence and Alzheimer disease: The egg and the chicken scenario. Nat. Rev. Neurosci. 2020, 21, 433-444. [CrossRef]

78. Sweeney, M.; Kisler, K.; Montagne, A.; Toga, A.W.; Zlokovic, B.V. The role of brain vasculature in neurodegenerative disorders. Nat. Neurosci. 2018, 21, 1318-1331. [CrossRef] [PubMed]

79. Belloy, M.; Napolioni, V.; Greicius, M.D. A Quarter Century of APOE and Alzheimer's Disease: Progress to Date and the Path Forward. Neuron 2019, 101, 820-838. [CrossRef] [PubMed]

80. Lewcock, J.W.; Schlepckow, K.; Di Paolo, G.; Tahirovic, S.; Monroe, K.M.; Haass, C. Emerging Microglia Biology Defines Novel Therapeutic Approaches for Alzheimer's Disease. Neuron 2020, 108, 801-821. [CrossRef]

81. Golde, T.E.; DeKosky, S.T.; Galasko, D. Alzheimer's disease: The right drug, the right time. Science 2018, 362, 1250-1251. [CrossRef] [PubMed]

82. Cummings, J.; Lee, G.; Ritter, A.; Sabbagh, M.; Zhong, K. Alzheimer's disease drug development pipeline: 2019. Alzheimer's Dementia: Transl. Res. Clin. Interv. 2019, 5, 272-293. [CrossRef]

83. Sevigny, J.; Chiao, P.; Bussière, T.; Weinreb, P.H.; Williams, L.; Maier, M.; Dunstan, R.; Salloway, S.; Chen, T.; Ling, Y.; et al. The antibody aducanumab reduces $A \beta$ plaques in Alzheimer's disease. Nature 2016, 537, 50-56. [CrossRef]

84. Sierksma, A.; Escott-Price, V.; De Strooper, B. Translating genetic risk of Alzheimer's disease into mechanistic insight and drug targets. Science 2020, 370, 61-66. [CrossRef]

85. Pérez, M.; Hernández, F.; Avila, J. Protein Biomarkers for the Diagnosis of Alzheimer's Disease at Different Stages of Neurodegeneration. Int. J. Mol. Sci. 2020, 21, 6749. [CrossRef]

86. Adaikkan, C.; Tsai, L.-H. Gamma Entrainment: Impact on Neurocircuits, Glia, and Therapeutic Opportunities. Trends Neurosci. 2020, 43, 24-41. [CrossRef]

87. Kastanenka, K.V.; Hou, S.S.; Shakerdge, N.; Logan, R.; Feng, D.; Wegmann, S.; Chopra, V.; Hawkes, J.M.; Chen, X.; Bacskai, B.J. Optogenetic Restoration of Disrupted Slow Oscillations Halts Amyloid Deposition and Restores Calcium Homeostasis in an Animal Model of Alzheimer's Disease. PLoS ONE 2017, 12, e0170275. [CrossRef]

88. Etter, G.; Van Der Veldt, S.; Manseau, F.; Zarrinkoub, I.; Trillaud-Doppia, E.; Williams, S. Optogenetic gamma stimulation rescues memory impairments in an Alzheimer's disease mouse model. Nat. Commun. 2019, 10, 1-11. [CrossRef]

89. Iaccarino, H.F.; Singer, A.C.; Martorell, A.J.; Rudenko, A.; Gao, F.; Gillingham, T.Z.; Mathys, H.; Seo, J.; Kritskiy, O.; Abdurrob, F.; et al. Gamma frequency entrainment attenuates amyloid load and modifies microglia. Nat. Cell Biol. 2016, 540, $230-235$. [CrossRef] [PubMed]

90. Martorell, A.J.; Paulson, A.; Suk, H.-J.; Abdurrob, F.; Drummond, G.T.; Guan, W.; Young, J.Z.; Kim, D.N.-W.; Kritskiy, O.; Barker, S.J.; et al. Multi-sensory Gamma Stimulation Ameliorates Alzheimer's-Associated Pathology and Improves Cognition. Cell 2019, 177, 256-271.e22. [CrossRef] [PubMed]

91. Adaikkan, C.; Middleton, S.; Marco, A.; Pao, P.-C.; Mathys, H.; Kim, D.N.-W.; Gao, F.; Young, J.Z.; Suk, H.-J.; Boyden, E.S.; et al. Gamma Entrainment Binds Higher-Order Brain Regions and Offers Neuroprotection. Neuron 2019, 102, 929-943.e8. [CrossRef] [PubMed]

92. Busche, M.A.; Kekuš, M.; Adelsberger, H.; Noda, T.; Förstl, H.; Nelken, I.; Konnerth, A. Rescue of long-range circuit dysfunction in Alzheimer's disease models. Nat. Neurosci. 2015, 18, 1623-1630. [CrossRef]

93. Isla, A.G.; Balleza-Tapia, H.; Fisahn, A. Efficacy of preclinical pharmacological interventions against alterations of neuronal network oscillations in Alzheimer's disease: A systematic review. Exp. Neurol. 2021, 343, 113743. [CrossRef]

94. Jasper, H.H.; Andrews, H.L. Brain potentials and voluntary muscle activity in man. J. Neurophysiol. 1938, 1, 87-100. [CrossRef]

95. Bressler, S.L.; Freeman, W.J. Frequency analysis of olfactory system EEG in cat, rabbit, and rat. Electroencephalogr. Clin. Neurophysiol. 1980, 50, 19-24. [CrossRef]

96. Freeman, W.J. Mass Action in the Nervous System; Academic Press: New York, NY, USA, 1975.

97. Nakazono, T.; Lam, T.N.; Patel, A.Y.; Kitazawa, M.; Saito, T.; Saido, T.C.; Igarashi, K.M. Impaired In Vivo Gamma Oscillations in the Medial Entorhinal Cortex of Knock-in Alzheimer Model. Front. Syst. Neurosci. 2017, 11, 48. [CrossRef] [PubMed]

98. Chrobak, J.J.; Buzsaki, G. Gamma Oscillations in the Entorhinal Cortex of the Freely Behaving Rat. J. Neurosci. 1998, 18, 388-398. [CrossRef]

99. Charpak, S.; Paré, D.; Llinás, R. The Entorhinal Cortex Entrains Fast CA1 Hippocampal Oscillations in the Anaesthetized Guinea-pig: Role of the Monosynaptic Component of the Perforant Path. Eur. J. Neurosci. 1995, 7, 1548-1557. [CrossRef] [PubMed]

100. Bauer, E.P.; Paz, R.; Paré, D. Gamma Oscillations Coordinate Amygdalo-Rhinal Interactions during Learning. J. Neurosci. 2007, 27, 9369-9379. [CrossRef]

101. Harris, K.; Csicsvari, J.; Hirase, H.; Dragoi, G.; Buzsaki, G. Organization of cell assemblies in the hippocampus. Nat. Cell Biol. 2003, 424, 552-556. [CrossRef] [PubMed]

102. Buzsaki, G.; Leung, L.-W.S.; Vanderwolf, C.H. Cellular bases of hippocampal EEG in the behaving rat. Brain Res. Rev. 1983, 6, 139-171. [CrossRef] 
103. Wang, X.-J.; Buzsaki, G. Gamma Oscillation by Synaptic Inhibition in a Hippocampal Interneuronal Network Model. J. Neurosci. 1996, 16, 6402-6413. [CrossRef]

104. Cohen, M.X.; Axmacher, N.; Lenartz, D.; Elger, C.E.; Sturm, V.; Schlaepfer, T. Good Vibrations: Cross-frequency Coupling in the Human Nucleus Accumbens during Reward Processing. J. Cogn. Neurosci. 2009, 21, 875-889. [CrossRef] [PubMed]

105. Popescu, A.T.; Popa, D.; Pare, D. Coherent gamma oscillations couple the amygdala and striatum during learning. Nat. Neurosci. 2009, 12, 801-807. [CrossRef] [PubMed]

106. Beshel, J.; Kopell, N.; Kay, L.M. Olfactory Bulb Gamma Oscillations Are Enhanced with Task Demands. J. Neurosci. 2007, 27, 8358-8365. [CrossRef]

107. Eeckman, F.H.; Freeman, W.J. Correlations between unit firing and EEG in the rat olfactory system. Brain Res. 1990, 528, 238-244. [CrossRef]

108. Yague, J.G.; Tsunematsu, T.; Sakata, S. Distinct Temporal Coordination of Spontaneous Population Activity between Basal Forebrain and Auditory Cortex. Front. Neural Circuits 2017, 11, 64. [CrossRef] [PubMed]

109. Nair, J.; Klaassen, A.-L.; Arato, J.; Vyssotski, A.L.; Harvey, M.; Rainer, G. Basal forebrain contributes to default mode network regulation. Proc. Natl. Acad. Sci. USA 2018, 115, 1352-1357. [CrossRef]

110. Minlebaev, M.; Colonnese, M.; Tsintsadze, T.; Sirota, A.; Khazipov, R. Early Gamma Oscillations Synchronize Developing Thalamus and Cortex. Science 2011, 334, 226-229. [CrossRef]

111. Jensen, O.; Kaiser, J.; Lachaux, J.-P. Human gamma-frequency oscillations associated with attention and memory. Trends Neurosci. 2007, 30, 317-324. [CrossRef] [PubMed]

112. Howard, M.W.; Rizzuto, D.S.; Caplan, J.B.; Madsen, J.R.; Lisman, J.; Aschenbrenner-Scheibe, R.; Schulze-Bonhage, A.; Kahana, M.J. Gamma Oscillations Correlate with Working Memory Load in Humans. Cereb. Cortex 2003, 13, 1369-1374. [CrossRef]

113. Osipova, D.; Takashima, A.; Oostenveld, R.; Fernandez, G.; Maris, E.; Jensen, O. Theta and Gamma Oscillations Predict Encoding and Retrieval of Declarative Memory. J. Neurosci. 2006, 26, 7523-7531. [CrossRef] [PubMed]

114. Tiesinga, P.; Sejnowski, T.J. Cortical Enlightenment: Are Attentional Gamma Oscillations Driven by ING or PING? Neuron 2009, 63, 727-732. [CrossRef]

115. Whittington, M.; Traub, R.; Kopell, N.; Ermentrout, B.; Buhl, E. Inhibition-based rhythms: Experimental and mathematical observations on network dynamics. Int. J. Psychophysiol. 2000, 38, 315-336. [CrossRef]

116. Traub, R.D.; Whittington, M.A.; Stanford, I.M.; Jefferys, J.G.R. A mechanism for generation of long-range synchronous fast oscillations in the cortex. Nat. Cell Biol. 1996, 383, 621-624. [CrossRef]

117. Lytton, W.W.; Sejnowski, T.J. Simulations of cortical pyramidal neurons synchronized by inhibitory interneurons. J. Neurophysiol. 1991, 66, 1059-1079. [CrossRef] [PubMed]

118. Traub, R.D.; Whittington, M.A.; Colling, S.B.; Buzsaki, G.; Jefferys, J.G. Analysis of gamma rhythms in the rat hippocampus in vitro and in vivo. J. Physiol. 1996, 493, 471-484. [CrossRef] [PubMed]

119. Whittington, M.A.; Traub, R.D.; Jefferys, J. Synchronized oscillations in interneuron networks driven by metabotropic glutamate receptor activation. Nat. Cell Biol. 1995, 373, 612-615. [CrossRef]

120. Cardin, J.A.; Carlen, M.; Meletis, K.; Knoblich, U.; Zhang, F.; Deisseroth, K.; Tsai, L.H.; Moore, C.I. Driving fast-spiking cells induces gamma rhythm and controls sensory responses. Nature 2009, 459, 663-667. [CrossRef]

121. Sohal, V.; Zhang, F.; Yizhar, O.; Deisseroth, K. Parvalbumin neurons and gamma rhythms enhance cortical circuit performance. Nat. Cell Biol. 2009, 459, 698-702. [CrossRef]

122. Jefferys, J.G.; Traub, R.D.; Whittington, M.A. Neuronal networks for induced ' $40 \mathrm{~Hz}$ ' rhythms. Trends Neurosci. 1996, 19, 202-208. [CrossRef]

123. Wilson, H.R.; Cowan, J.D. Excitatory and Inhibitory Interactions in Localized Populations of Model Neurons. Biophys. J. 1972, 12, 1-24. [CrossRef]

124. Tiesinga, P.; Fellous, J.-M.; Sejnowski, T.J. Regulation of spike timing in visual cortical circuits. Nat. Rev. Neurosci. 2008, 9, 97-107. [CrossRef]

125. Fisahn, A.; Pike, F.G.; Buhl, E.H.; Paulsen, O. Cholinergic induction of network oscillations at $40 \mathrm{~Hz}$ in the hippocampus in vitro. Nat. Cell Biol. 1998, 394, 186-189. [CrossRef] [PubMed]

126. Andersson, R.; Galter, D.; Papadia, D.; Fisahn, A. Histamine induces KCNQ channel-dependent gamma oscillations in rat hippocampus via activation of the $\mathrm{H} 1$ receptor. Neuropharmacology 2017, 118, 13-25. [CrossRef]

127. Gray, C.M.; McCormick, D.A. Chattering Cells: Superficial Pyramidal Neurons Contributing to the Generation of Synchronous Oscillations in the Visual Cortex. Science 1996, 274, 109-113. [CrossRef] [PubMed]

128. Ribary, U.; Ioannides, A.A.; Singh, K.; Hasson, R.; Bolton, J.P.; Lado, F.; Mogilner, A.; Llinas, R. Magnetic field tomography of coherent thalamocortical 40-Hz oscillations in humans. Proc. Natl. Acad. Sci. USA 1991, 88, 11037-11041. [CrossRef]

129. Başar, E.; Emek-Savaş, D.D.; Güntekin, B.; Yener, G.G. Delay of cognitive gamma responses in Alzheimer's disease. NeuroImage: Clin. 2016, 11, 106-115. [CrossRef]

130. Van Deursen, J.; Vuurman, E.; van Kranen-Mastenbroek, V.; Verhey, F.; Riedel, W. 40-Hz steady state response in Alzheimer's disease and mild cognitive impairment. Neurobiol. Aging 2011, 32, 24-30. [CrossRef]

131. Rossini, P.; Del Percio, C.; Pasqualetti, P.; Cassetta, E.; Binetti, G.; Forno, G.D.; Ferreri, F.; Frisoni, G.B.; Chiovenda, P.; Miniussi, C.; et al. Conversion from mild cognitive impairment to Alzheimer's disease is predicted by sources and coherence of brain electroencephalography rhythms. Neuroscience 2006, 143, 793-803. [CrossRef] 
132. Başar, E.; Femir, B.; Emek-Savaş, D.D.; Güntekin, B.; Yener, G.G. Increased long distance event-related gamma band connectivity in Alzheimer's disease. NeuroImage: Clin. 2017, 14, 580-590. [CrossRef] [PubMed]

133. Wang, J.; Fang, Y.; Wang, X.; Yang, H.; Yu, X.; Wang, H. Enhanced Gamma Activity and Cross-Frequency Interaction of Resting-State Electroencephalographic Oscillations in Patients with Alzheimer's Disease. Front. Aging Neurosci. $2017,9,243$. [CrossRef] [PubMed]

134. Koenig, T.; Prichep, L.; Dierks, T.; Hubl, D.; Wahlund, L.; John, E.; Jelic, V. Decreased EEG synchronization in Alzheimer's disease and mild cognitive impairment. Neurobiol. Aging 2005, 26, 165-171. [CrossRef] [PubMed]

135. Gaubert, S.; Raimondo, F.; Houot, M.; Corsi, M.-C.; Naccache, L.; Sitt, J.D.; Hermann, B.; Oudiette, D.; Gagliardi, G.; Habert, M.-O.; et al. EEG evidence of compensatory mechanisms in preclinical Alzheimer's disease. Brain 2019, 142, 20962112. [CrossRef] [PubMed]

136. Jones, D.T.; Knopman, D.S.; Gunter, J.L.; Graff-Radford, J.; Vemuri, P.; Boeve, B.F.; Petersen, R.C.; Weiner, M.W.; Jack, C.R. Cascading network failure across the Alzheimer's disease spectrum. Brain 2016, 139, 547-562. [CrossRef] [PubMed]

137. Lim, H.K.; Nebes, R.; Snitz, B.; Cohen, A.; Mathis, C.; Price, J.; Weissfeld, L.; Klunk, W.; Aizenstein, H.J. Regional amyloid burden and intrinsic connectivity networks in cognitively normal elderly subjects. Brain 2014, 137, 3327-3338. [CrossRef]

138. Mormino, E.C.; Smiljic, A.; Hayenga, A.O.; Onami, S.H.; Greicius, M.D.; Rabinovici, G.D.; Janabi, M.; Baker, S.L.; Yen, I.V.; Madison, C.M.; et al. Relationships between Beta-Amyloid and Functional Connectivity in Different Components of the Default Mode Network in Aging. Cereb. Cortex 2011, 21, 2399-2407. [CrossRef]

139. Klein, A.S.; Donoso, J.R.; Kempter, R.; Schmitz, D.; Beed, P. Early Cortical Changes in Gamma Oscillations in Alzheimer's Disease. Front. Syst. Neurosci. 2016, 10, 83. [CrossRef]

140. Verret, L.; Mann, E.; Hang, G.B.; Barth, A.M.; Cobos, I.; Ho, K.; Devidze, N.; Masliah, E.; Kreitzer, A.C.; Mody, I.; et al. Inhibitory Interneuron Deficit Links Altered Network Activity and Cognitive Dysfunction in Alzheimer Model. Cell 2012, 149, 708-721. [CrossRef]

141. Martinez-Losa, M.; Tracy, T.E.; Ma, K.; Verret, L.; Clemente-Perez, A.; Khan, A.S.; Cobos, I.; Ho, K.; Gan, L.; Mucke, L.; et al. Nav1.1-Overexpressing Interneuron Transplants Restore Brain Rhythms and Cognition in a Mouse Model of Alzheimer's Disease. Neuron 2018, 98, 75-89. [CrossRef]

142. Goutagny, R.; Gu, N.; Cavanagh, C.; Jackson, J.; Chabot, J.-G.; Quirion, R.; Krantic, S.; Williams, S. Alterations in hippocampal network oscillations and theta-gamma coupling arise before $\mathrm{A} \beta$ overproduction in a mouse model of Alzheimer's disease. Eur. J. Neurosci. 2013, 37, 1896-1902. [CrossRef]

143. Hamm, V.; Héraud, C.; Bott, J.-B.; Herbeaux, K.; Strittmatter, C.; Mathis, C.; Goutagny, R. Differential contribution of APP metabolites to early cognitive deficits in a TgCRND8 mouse model of Alzheimer's disease. Sci. Adv. 2017, 3, e1601068. [CrossRef]

144. Jones, E.A.; Gillespie, A.K.; Yoon, S.Y.; Frank, L.; Huang, Y. Early Hippocampal Sharp-Wave Ripple Deficits Predict Later Learning and Memory Impairments in an Alzheimer's Disease Mouse Model. Cell Rep. 2019, 29, 2123-2133.e4. [CrossRef] [PubMed]

145. Gillespie, A.K.; Jones, E.A.; Lin, Y.-H.; Karlsson, M.P.; Kay, K.; Yoon, S.Y.; Tong, L.M.; Nova, P.; Carr, J.S.; Frank, L.; et al. Apolipoprotein E4 Causes Age-Dependent Disruption of Slow Gamma Oscillations during Hippocampal Sharp-Wave Ripples. Neuron 2016, 90, 740-751. [CrossRef]

146. Richetin, K.; Steullet, P.; Pachoud, M.; Perbet, R.; Parietti, E.; Maheswaran, M.; Eddarkaoui, S.; Bégard, S.; Pythoud, C.; Rey, M.; et al. Tau accumulation in astrocytes of the dentate gyrus induces neuronal dysfunction and memory deficits in Alzheimer's disease. Nat. Neurosci. 2020, 23, 1567-1579. [CrossRef] [PubMed]

147. Zhang, X.; Zhong, W.; Brankačk, J.; Weyer, S.W.; Müller, U.C.; Tort, A.B.L.; Draguhn, A. Impaired theta-gamma coupling in APP-deficient mice. Sci. Rep. 2016, 6, 21948. [CrossRef] [PubMed]

148. Shi, A.; Petrache, A.L.; Shi, J.; Ali, A.B. Preserved Calretinin Interneurons in an App Model of Alzheimer's Disease Disrupt Hippocampal Inhibition via Upregulated P2Y1 Purinoreceptors. Cereb. Cortex 2019, 30, 1272-1290. [CrossRef] [PubMed]

149. Fu, H.; Possenti, A.; Freer, R.; Nakano, Y.; Villegas, N.C.H.; Tang, M.; Cauhy, P.V.M.; Lassus, B.A.; Chen, S.; Fowler, S.L.; et al. A tau homeostasis signature is linked with the cellular and regional vulnerability of excitatory neurons to tau pathology. Nat. Neurosci. 2018, 22, 47-56. [CrossRef]

150. Mathys, H.; Davila-Velderrain, J.; Peng, Z.; Gao, F.; Mohammadi, S.; Young, J.Z.; Menon, M.; He, L.; Abdurrob, F.; Jiang, X.; et al. Single-cell transcriptomic analysis of Alzheimer's disease. Nature 2019, 570, 332-337. [CrossRef]

151. Zalocusky, K.A.; Najm, R.; Taubes, A.L.; Hao, Y.; Yoon, S.Y.; Koutsodendris, N.; Nelson, M.R.; Rao, A.; Bennett, D.A.; Bant, J.; et al. Neuronal ApoE upregulates MHC-I expression to drive selective neurodegeneration in Alzheimer's disease. Nat. Neurosci. 2021, 24, 786-798. [CrossRef] [PubMed]

152. Leng, K.; Li, E.; Eser, R.; Piergies, A.; Sit, R.; Tan, M.; Neff, N.; Li, S.H.; Rodriguez, R.D.; Suemoto, C.K.; et al. Molecular characterization of selectively vulnerable neurons in Alzheimer's disease. Nat. Neurosci. 2021, 24, 276-287. [CrossRef]

153. Roussarie, J.-P.; Yao, V.; Rodriguez, P.R.; Oughtred, R.; Rust, J.; Plautz, Z.; Kasturia, S.; Albornoz, C.; Wang, W.; Schmidt, E.F.; et al. Selective Neuronal Vulnerability in Alzheimer's Disease: A Network-Based Analysis. Neuron 2020, 107, 821-835.e12. [CrossRef]

154. Ahnaou, A.; Moechars, D.; Raeymaekers, L.; Biermans, R.; Manyakov, N.V.; Bottelbergs, A.; Wintmolders, C.; Van Kolen, K.; Van De Casteele, T.; Kemp, J.A.; et al. Emergence of early alterations in network oscillations and functional connectivity in a tau seeding mouse model of Alzheimer's disease pathology. Sci. Rep. 2017, 7, 14189. [CrossRef] 
155. Hermann, D.; Both, M.; Ebert, U.; Gross, G.; Schoemaker, H.; Draguhn, A.; Wicke, K.; Nimmrich, V. Synaptic transmission is impaired prior to plaque formation in amyloid precursor protein-overexpressing mice without altering behaviorally-correlated sharp wave-ripple complexes. Neuroscience 2009, 162, 1081-1090. [CrossRef]

156. Oblak, A.L.; Forner, S.; Territo, P.R.; Sasner, M.; Carter, G.W.; Howell, G.R.; Sukoff-Rizzo, S.J.; Logsdon, B.A.; Mangravite, L.M.; Mortazavi, A.; et al. Model organism development and evaluation for late-onset Alzheimer's disease: MODEL-AD. Alzheimer's Dementia Transl. Res. Clin. Interv. 2020, 6. [CrossRef]

157. Wilson, C.A.; Fouda, S.; Sakata, S. Effects of optogenetic stimulation of basal forebrain parvalbumin neurons on Alzheimer's disease pathology. Sci. Rep. 2020, 10, 1-9. [CrossRef]

158. Bobola, M.; Chen, L.; Ezeokeke, C.; Olmstead, T.; Nguyen, C.; Sahota, A.; Williams, R.; Mourad, P. Transcranial focused ultrasound, pulsed at $40 \mathrm{~Hz}$, activates microglia acutely and reduces $\mathrm{A} \beta$ load chronically, as demonstrated in vivo. Brain Stimul. 2020, 13, 1014-1023. [CrossRef] [PubMed]

159. Park, S.-S.; Park, H.-S.; Kim, C.-J.; Kang, H.-S.; Kim, D.-H.; Baek, S.-S.; Kim, T.-W. Physical exercise during exposure to 40-Hz light flicker improves cognitive functions in the 3xTg mouse model of Alzheimer's disease. Alzheimer's Res. Ther. 2020, 12, 1-15. [CrossRef]

160. Yao, Y.; Ying, Y.; Deng, Q.; Zhang, W.; Zhu, H.; Lin, Z.; Zhang, S.; Ma, J.; Zhao, Y. Non-invasive 40-Hz Light Flicker Ameliorates Alzheimer's-Associated Rhythm Disorder via Regulating Central Circadian Clock in Mice. Front. Physiol. 2020, 11, 294. [CrossRef]

161. Freund, T.F.; Meskenaite, V. gamma-Aminobutyric acid-containing basal forebrain neurons innervate inhibitory interneurons in the neocortex. Proc. Natl. Acad. Sci. USA 1992, 89, 738-742. [CrossRef] [PubMed]

162. Klunk, W.; Bacskai, B.J.; Mathis, C.A.; Kajdasz, S.T.; McLellan, M.E.; Frosch, M.P.; Debnath, M.L.; Holt, D.P.; Wang, Y.; Hyman, B.T. Imaging A $\beta$ Plaques in Living Transgenic Mice with Multiphoton Microscopy and Methoxy-X04, a Systemically Administered Congo Red Derivative. J. Neuropathol. Exp. Neurol. 2002, 61, 797-805. [CrossRef]

163. Steriade, M.; Nuñez, A.; Amzica, F. Intracellular analysis of relations between the slow $(<1 \mathrm{~Hz})$ neocortical oscillation and other sleep rhythms of the electroencephalogram. J. Neurosci. 1993, 13, 3266-3283. [CrossRef]

164. Steriade, M.; Contreras, D.; Dossi, R.C.; Nunez, A. The slow $(<1 \mathrm{~Hz})$ oscillation in reticular thalamic and thalamocortical neurons: Scenario of sleep rhythm generation in interacting thalamic and neocortical networks. J. Neurosci 1993, 13, 3284-3299. [CrossRef]

165. Sakata, S.; Harris, K.D. Laminar-dependent effects of cortical state on auditory cortical spontaneous activity. Front. Neural Circuits 2012, 6, 109. [CrossRef] [PubMed]

166. Sakata, S.; Harris, K.D. Laminar Structure of Spontaneous and Sensory-Evoked Population Activity in Auditory Cortex. Neuron 2009, 64, 404-418. [CrossRef]

167. Luczak, A.; Bartho, P.; Marguet, S.L.; Buzsaki, G.; Harris, K.D. Sequential structure of neocortical spontaneous activity in vivo. Proc. Natl. Acad. Sci. USA 2007, 104, 347-352. [CrossRef]

168. Chauvette, S.; Volgushev, M.; Timofeev, I. Origin of Active States in Local Neocortical Networks during Slow Sleep Oscillation. Cereb. Cortex 2010, 20, 2660-2674. [CrossRef]

169. Timofeev, I.; Grenier, F.; Bazhenov, M.; Sejnowski, T.; Steriade, M. Origin of Slow Cortical Oscillations in Deafferented Cortical Slabs. Cereb. Cortex 2000, 10, 1185-1199. [CrossRef] [PubMed]

170. Isomura, Y.; Sirota, A.; Özen, S.; Montgomery, S.; Mizuseki, K.; Henze, D.A.; Buzsáki, G. Integration and Segregation of Activity in Entorhinal-Hippocampal Subregions by Neocortical Slow Oscillations. Neuron 2006, 52, 871-882. [CrossRef]

171. Hughes, S.W.; Cope, D.W.; Blethyn, K.L.; Crunelli, V. Cellular Mechanisms of the Slow (<1 Hz) oscillation in thalamocortical neurons in vitro. Neuron 2002, 33, 947-958. [CrossRef]

172. David, F.; Schmiedt, J.T.; Taylor, H.L.; Orban, G.; Di Giovanni, G.; Uebele, V.N.; Renger, J.J.; Lambert, R.C.; LeResche, N.; Crunelli, V. Essential thalamic contribution to slow waves of natural sleep. J. Neurosci. 2013, 33, 19599-19610. [CrossRef]

173. Blethyn, K.L.; Hughes, S.W.; Tóth, T.I.; Cope, D.W.; Crunelli, V. Neuronal Basis of the Slow $(<1 \mathrm{~Hz})$ oscillation in neurons of the nucleus reticularis thalami in vitro. J. Neurosci 2006, 26, 2474-2486. [CrossRef] [PubMed]

174. Wilson, C.J. Chapter 18 The generation of natural firing patterns in neostriatal neurons. Prog. Brain Res. 1993, 99, $277-297$. [CrossRef] [PubMed]

175. Wilson, C.J.; Groves, P.M. Spontaneous firing patterns of identified spiny neurons in the rat neostriatum. Brain Res. 1981, 220, 67-80. [CrossRef]

176. Mena-Segovia, J.; Sims, H.M.; Magill, P.J.; Bolam, J.P. Cholinergic brainstem neurons modulate cortical gamma activity during slow oscillations. J. Physiol. 2008, 586, 2947-2960. [CrossRef]

177. Narikiyo, K.; Mizuguchi, R.; Ajima, A.; Shiozaki, M.; Hamanaka, H.; Johansen, J.P.; Mori, K.; Yoshihara, Y. The claustrum coordinates cortical slow-wave activity. Nat. Neurosci. 2020, 23, 741-753. [CrossRef]

178. Timofeev, I.; Chauvette, S. Sleep slow oscillation and plasticity. Curr. Opin. Neurobiol. 2017, 44, 116-126. [CrossRef]

179. Kang, J.-E.; Lim, M.M.; Bateman, R.J.; Lee, J.J.; Smyth, L.P.; Cirrito, J.R.; Fujiki, N.; Nishino, S.; Holtzman, D.M. Amyloid- $\beta$ Dynamics Are Regulated by Orexin and the Sleep-Wake Cycle. Science 2009, 326, 1005-1007. [CrossRef]

180. Holth, J.K.; Fritschi, S.K.; Wang, C.; Pedersen, N.P.; Cirrito, J.R.; Mahan, T.E.; Finn, M.B.; Manis, M.; Geerling, J.C.; Fuller, P.M.; et al. The sleep-wake cycle regulates brain interstitial fluid tau in mice and CSF tau in humans. Science 2019, 363, 880-884. [CrossRef]

181. Nedergaard, M.; Goldman, S.A. Glymphatic failure as a final common pathway to dementia. Science 2020, 370, 50-56. [CrossRef] 
182. Gagnon, J.; Lafreniere, A.; Rauchs, G.; Petit, D.; Carrier, J. Sleep in normal aging, Alzheimer's disease, and mild cognitive impairment. In Handbook of Sleep Research; Dringenberg, H.C., Ed.; Elsevier: Amsterdam, The Netherlands, 2019; Volume 30, pp. 677-692.

183. Ning, S.; Jorfi, M. Beyond the sleep-amyloid interactions in Alzheimer's disease pathogenesis. J. Neurophysiol. 2019, 122, 1-4. [CrossRef]

184. Sanchez-Vives, M.V. Origin and dynamics of cortical slow oscillations. Curr. Opin. Physiol. 2020, 15, 217-223. [CrossRef]

185. Noya, S.B.; Colameo, D.; Brüning, F.; Spinnler, A.; Mircsof, D.; Opitz, L.; Mann, M.; Tyagarajan, S.K.; Robles, M.S.; Brown, S.A. The forebrain synaptic transcriptome is organized by clocks but its proteome is driven by sleep. Science 2019, 366, eaav2642. [CrossRef]

186. Brüning, F.; Noya, S.B.; Bange, T.; Koutsouli, S.; Rudolph, J.D.; Tyagarajan, S.K.; Cox, J.; Mann, M.; Brown, S.A.; Robles, M.S. Sleep-wake cycles drive daily dynamics of synaptic phosphorylation. Science 2019, 366, eaav3617. [CrossRef]

187. Borbély, A.A. A two process model of sleep regulation. Hum. Neurobiol. 1982, 1, 195-204.

188. Timofeev, I.; Steriade, M. Low-frequency rhythms in the thalamus of intact-cortex and decorticated cats. J. Neurophysiol. 1996, 76, 4152-4168. [CrossRef]

189. Sanchez-Vives, M.; McCormick, D.A. Cellular and network mechanisms of rhythmic recurrent activity in neocortex. Nat. Neurosci. 2000, 3, 1027-1034. [CrossRef]

190. Beltramo, R.; D’Urso, G.; Maschio, M.D.; Farisello, P.; Bovetti, S.; Clovis, Y.; Lassi, G.; Tucci, V.; Tonelli, D.D.P.; Fellin, T. Layer-specific excitatory circuits differentially control recurrent network dynamics in the neocortex. Nat. Neurosci. 2013, 16, 227-234. [CrossRef]

191. Levenstein, D.; Buzsáki, G.; Rinzel, J. NREM sleep in the rodent neocortex and hippocampus reflects excitable dynamics. Nat. Commun. 2019, 10, 1-12. [CrossRef]

192. Hill, S.; Tononi, G. Modeling Sleep and Wakefulness in the Thalamocortical System. J. Neurophysiol. 2005, 93, 1671-1698. [CrossRef]

193. Destexhe, A. Self-sustained asynchronous irregular states and Up-Down states in thalamic, cortical and thalamocortical networks of nonlinear integrate-and-fire neurons. J. Comput. Neurosci. 2009, 27, 493-506. [CrossRef]

194. Bazhenov, M.; Timofeev, I.; Steriade, M.; Sejnowski, T.J. Model of Thalamocortical Slow-Wave Sleep Oscillations and Transitions to Activated States. J. Neurosci. 2002, 22, 8691-8704. [CrossRef]

195. Compte, A.; Sanchez-Vives, M.; McCormick, D.A.; Wang, X.-J. Cellular and Network Mechanisms of Slow Oscillatory Activity $(<1 \mathrm{~Hz})$ and wave propagations in a cortical network model. J. Neurophysiol. 2003, 89, 2707-2725. [CrossRef]

196. Fröhlich, F.; Bazhenov, M.; Timofeev, I.; Steriade, M.; Sejnowski, T.J. Slow State Transitions of Sustained Neural Oscillations by Activity-Dependent Modulation of Intrinsic Excitability. J. Neurosci. 2006, 26, 6153-6162. [CrossRef]

197. Shu, Y.; Hasenstaub, A.; McCormick, D.A. Turning on and off recurrent balanced cortical activity. Nat. Cell Biol. 2003, 423, 288-293. [CrossRef]

198. Zucca, S.; D’Urso, G.; Pasquale, V.; Vecchia, D.; Pica, G.; Bovetti, S.; Moretti, C.; Varani, S.; Mazon, M.M.; Chiappalone, M.; et al. An inhibitory gate for state transition in cortex. eLife 2017, 6, e26177. [CrossRef]

199. Valero, M.; Viney, T.J.; Machold, R.; Mederos, S.; Zutshi, I.; Schuman, B.; Senzai, Y.; Rudy, B.; Buzsáki, G. Sleep down state-active ID2/Nkx2.1 interneurons in the neocortex. Nat. Neurosci. 2021, 24, 401-411. [CrossRef]

200. Parga, N.; Abbott, L.F. Network model of spontaneous activity exhibiting synchronous transitions between up and down states. Front. Behav. Neurosci. 2007, 1, 57-66. [CrossRef] [PubMed]

201. Jercog, D.; Roxin, A.; Barthó, P.; Luczak, A.; Compte, A.; De La Rocha, J. UP-DOWN cortical dynamics reflect state transitions in a bistable network. eLife 2017, 6, e22425. [CrossRef]

202. Zucca, S.; Pasquale, V.; Roig, P.L.D.L.; Panzeri, S.; Fellin, T. Thalamic Drive of Cortical Parvalbumin-Positive Interneurons during Down States in Anesthetized Mice. Curr. Biol. 2019, 29, 1481-1490.e6. [CrossRef]

203. Bojarskaite, L.; Bjørnstad, D.M.; Pettersen, K.H.; Cunen, C.; Hermansen, G.H.; Åbjørsbråten, K.S.; Chambers, A.R.; Sprengel, R.; Vervaeke, K.; Tang, W.; et al. Astrocytic Ca2+ signaling is reduced during sleep and is involved in the regulation of slow wave sleep. Nat. Commun. 2020, 11,1-16. [CrossRef]

204. Buskila, Y.; Bellot-Saez, A.; Morley, J.W. Generating Brain Waves, the Power of Astrocytes. Front. Neurosci. 2019, 13, 1125. [CrossRef] [PubMed]

205. Szabó, Z.; Héja, L.; Szalay, G.; Kékesi, O.; Füredi, A.; Szebényi, K.; Dobolyi, Á.; Orbán, T.I.; Kolacsek, O.; Tompa, T.; et al. Extensive astrocyte synchronization advances neuronal coupling in slow wave activity in vivo. Sci. Rep. 2017, 7, 1-18. [CrossRef] [PubMed]

206. Hirase, H.; Qian, L.; Barthó, P.; Buzsaki, G. Calcium Dynamics of Cortical Astrocytic Networks In Vivo. PLoS Biol. 2004, 2, e96. [CrossRef]

207. Amzica, F.; Steriade, M. Neuronal and Glial Membrane Potentials during Sleep and Paroxysmal Oscillations in the Neocortex. J. Neurosci. 2000, 20, 6648-6665. [CrossRef]

208. Timofeev, I.; Schoch, S.; LeBourgeois, M.K.; Huber, R.; Riedner, B.A.; Kurth, S. Spatio-temporal properties of sleep slow waves and implications for development. Curr. Opin. Physiol. 2020, 15, 172-182. [CrossRef]

209. Billeh, Y.N.; Cai, B.; Gratiy, S.L.; Dai, K.; Iyer, R.; Gouwens, N.W.; Abbasi-Asl, R.; Jia, X.; Siegle, J.H.; Olsen, S.R.; et al. Systematic Integration of Structural and Functional Data into Multi-scale Models of Mouse Primary Visual Cortex. Neuron 2020, 106, 388-403.e18. [CrossRef]

210. Markram, H.; Muller, E.; Ramaswamy, S.; Reimann, M.W.; Abdellah, M.; Sanchez, C.A.; Ailamaki, A.; Alonso-Nanclares, L.; Antille, N.; Arsever, S.; et al. Reconstruction and Simulation of Neocortical Microcircuitry. Cell 2015, 163, 456-492. [CrossRef] 
211. Nir, Y.; Staba, R.J.; Andrillon, T.; Vyazovskiy, V.; Cirelli, C.; Fried, I.; Tononi, G. Regional Slow Waves and Spindles in Human Sleep. Neuron 2011, 70, 153-169. [CrossRef]

212. Murphy, M.; Riedner, B.A.; Huber, R.; Massimini, M.; Ferrarelli, F.; Tononi, G. Source modeling sleep slow waves. Proc. Natl. Acad. Sci. USA 2009, 106, 1608-1613. [CrossRef]

213. Massimini, M.; Huber, R.; Ferrarelli, F.; Hill, S.; Tononi, G. The Sleep Slow Oscillation as a Traveling Wave. J. Neurosci. 2004, 24, 6862-6870. [CrossRef] [PubMed]

214. Burke, S.L.; Hu, T.; Spadola, C.; Burgess, A.; Li, T.; Cadet, T. Treatment of Sleep Disturbance May Reduce the Risk of Future Probable Alzheimer's Disease. J. Aging Health 2019, 31, 322-342. [CrossRef] [PubMed]

215. Keage, H.A.D.; Banks, S.; Yang, K.L.; Morgan, K.; Brayne, C.; Matthews, F. What sleep characteristics predict cognitive decline in the elderly? Sleep Med. 2012, 13, 886-892. [CrossRef] [PubMed]

216. Lim, A.S.P.; Kowgier, M.; Yu, L.; Buchman, A.S.; Bennett, D.A. Sleep Fragmentation and the Risk of Incident Alzheimer's Disease and Cognitive Decline in Older Persons. Sleep 2013, 36, 1027-1032. [CrossRef] [PubMed]

217. Petrovsky, D.V.; McPhillips, M.V.; Li, J.; Brody, A.; Caffeé, L.; Hodgson, N.A. Sleep disruption and quality of life in persons with dementia: A state-of-the-art review. Geriatr. Nurs. 2018, 39, 640-645. [CrossRef]

218. Potvin, O.; Lorrain, D.; Forget, H.; Dubé, M.; Grenier, S.; Préville, M.; Hudon, C. Sleep Quality and 1-Year Incident Cognitive Impairment in Community-Dwelling Older Adults. Sleep 2012, 35, 491-499. [CrossRef]

219. Sindi, S.; Kåreholt, I.; Johansson, L.; Skoog, J.; Sjöberg, L.; Wang, H.-X.; Johansson, B.; Fratiglioni, L.; Soininen, H.; Solomon, A.; et al. Sleep disturbances and dementia risk: A multicenter study. Alzheimer's Dement. 2018, 14, 1235-1242. [CrossRef]

220. Yaffe, K.; Nettiksimmons, J.; Yesavage, J.; Byers, A. Sleep Quality and Risk of Dementia Among Older Male Veterans. Am. J. Geriatr. Psychiatry 2015, 23, 651-654. [CrossRef]

221. Bliwise, D.; Tinklenberg, J.; Yesavage, J.; Davies, H.; Pursley, A.; Petta, D.; Widrow, L.; Guilleminault, C.; Zarcone, V.; Dement, W. REM latency in Alzheimer's disease. Biol. Psychiatry 1989, 25, 320-328. [CrossRef]

222. Liguori, C.; Placidi, F.; Izzi, F.; Spanetta, M.; Mercuri, N.B.; Di Pucchio, A. Sleep dysregulation, memory impairment, and CSF biomarkers during different levels of neurocognitive functioning in Alzheimer's disease course. Alzheimer's Res. Ther. 2020, 12, 1-13. [CrossRef]

223. Liguori, C.; Romigi, A.; Nuccetelli, M.; Zannino, S.; Sancesario, G.; Martorana, A.; Albanese, M.; Mercuri, N.B.; Izzi, F.; Bernardini, S.; et al. Orexinergic System Dysregulation, Sleep Impairment, and Cognitive Decline in Alzheimer Disease. JAMA Neurol. 2014, 71, 1498-1505. [CrossRef]

224. Liu, S.; Pan, J.; Tang, K.; Lei, Q.; He, L.; Meng, Y.; Cai, X.; Li, Z. Sleep spindles, K-complexes, limb movements and sleep stage proportions may be biomarkers for amnestic mild cognitive impairment and Alzheimer's disease. Sleep Breath. 2019, 24, 637-651. [CrossRef]

225. Loewenstein, R.J.; Weingartner, H.; Gillin, J.; Kaye, W.; Ebert, M.; Mendelson, W.B. Disturbances of sleep and cognitive functioning in patients with dementia. Neurobiol. Aging 1982, 3, 371-377. [CrossRef]

226. Vitiello, M.V.; Prinz, P.N.; Williams, D.E.; Frommlet, M.S.; Ries, R.K. Sleep Disturbances in Patients With Mild-Stage Alzheimer's Disease. J. Gerontol. 1990, 45, M131-M138. [CrossRef]

227. Prinz, P.N.; Vitaliano, P.P.; Vitiello, M.V.; Bokan, J.; Raskind, M.; Peskind, E.; Gerber, C. Sleep, EEG and mental function changes in senile dementia of the Alzheimer's type. Neurobiol. Aging 1982, 3, 361-370. [CrossRef]

228. Prinz, P.N.; Peskind, E.R.; Vitaliano, P.P.; Raskind, M.A.; Eisdorfer, C.; Zemcuznikov, H.N.; Gerber, C.J. Changes in the Sleep and Waking EEGs of Nondemented and Demented Elderly Subjects. J. Am. Geriatr. Soc. 1982, 30, 86-92. [CrossRef]

229. Moe, K.E.; Vitiello, M.V.; Larsen, L.H.; Prinz, P.N. Sleep/wake patterns In Alzheimer's disease: Relationships with cognition and function. J. Sleep Res. 1995, 4, 15-20. [CrossRef]

230. Mander, A.B.; Rao, V.; Lu, B.; Saletin, J.; Lindquist, J.R.; Ancoli-Israel, S.; Jagust, W.; Walker, M.P. Prefrontal atrophy, disrupted NREM slow waves and impaired hippocampal-dependent memory in aging. Nat. Neurosci. 2013, 16, 357-364. [CrossRef]

231. Mander, B.A.; Marks, S.M.; Vogel, J.W.; Rao, V.; Lu, B.; Saletin, J.M.; Ancoli-Israel, S.; Jagust, W.J.; Walker, M.P. $\beta$-amyloid disrupts human NREM slow waves and related hippocampus-dependent memory consolidation. Nat. Neurosci. 2015, 18, 1051-1057. [CrossRef]

232. Lucey, B.P.; McCullough, A.; Landsness, E.C.; Toedebusch, C.D.; McLeland, J.S.; Zaza, A.M.; Fagan, A.M.; McCue, L.; Xiong, C.; Morris, J.C.; et al. Reduced non-rapid eye movement sleep is associated with tau pathology in early Alzheimer's disease. Sci. Transl. Med. 2019, 11, eaau6550. [CrossRef]

233. Castano-Prat, P.; Perez-Mendez, L.; Perez-Zabalza, M.; Sanfeliu, C.; Giménez-Llort, L.; Sanchez-Vives, M.V. Altered slow (<1 Hz) and fast (beta and gamma) neocortical oscillations in the 3xTg-AD mouse model of Alzheimer's disease under anes-thesia. Neurobiol. Aging 2019, 79, 142-151. [CrossRef]

234. Kent, B.; Strittmatter, S.; Nygaard, H.B. Sleep and EEG Power Spectral Analysis in Three Transgenic Mouse Models of Alzheimer's Disease: APP/PS1, 3xTgAD, and Tg2576. J. Alzheimer's Dis. 2018, 64, 1325-1336. [CrossRef] [PubMed]

235. Roh, J.H.; Huang, Y.; Bero, A.W.; Kasten, T.; Stewart, F.R.; Bateman, R.; Holtzman, D.M. Disruption of the Sleep-Wake Cycle and Diurnal Fluctuation of -Amyloid in Mice with Alzheimer's Disease Pathology. Sci. Transl. Med. 2012, 4, 150ra122. [CrossRef]

236. Zhang, B.; Veasey, S.C.; Wood, M.A.; Leng, L.Z.; Kaminski, C.; Leight, S.; Abel, T.; Lee, V.M.-Y.; Trojanowski, J.Q. Impaired Rapid Eye Movement Sleep in the Tg2576 APP Murine Model of Alzheimer's Disease with Injury to Pedunculopontine Cholinergic Neurons. Am. J. Pathol. 2005, 167, 1361-1369. [CrossRef] 
237. Holth, J.K.; Mahan, T.E.; Robinson, G.O.; da Rocha, A.S.; Holtzman, D.M. Altered sleep and EEG power in the P301S Tau transgenic mouse model. Ann. Clin. Transl. Neurol. 2017, 4, 180-190. [CrossRef]

238. Holton, C.M.; Hanley, N.; Shanks, E.; Oxley, P.; McCarthy, A.; Eastwood, B.J.; Murray, T.K.; Nickerson, A.; Wafford, K.A. Longitudinal changes in EEG power, sleep cycles and behaviour in a tau model of neurodegeneration. Alzheimer's Res. Ther. 2020, 12, 1-15. [CrossRef]

239. Jyoti, A.; Plano, A.; Riedel, G.; Platt, B. Progressive age-related changes in sleep and EEG profiles in the PLB1Triple mouse model of Alzheimer's disease. Neurobiol. Aging 2015, 36, 2768-2784. [CrossRef]

240. Koss, D.J.; Robinson, L.; Drever, B.D.; Plucinska, K.; Stoppelkamp, S.; Veselcic, P.; Riedel, G.; Platt, B. Mutant Tau knock-in mice display frontotemporal dementia relevant behaviour and histopathology. Neurobiol. Dis. 2016, 91, 105-123. [CrossRef]

241. Kastanenka, K.V.; Calvo-Rodriguez, M.; Hou, S.S.; Zhou, H.; Takeda, S.; Arbel-Ornath, M.; Lariviere, A.; Lee, Y.F.; Kim, A.; Hawkes, J.M.; et al. Frequency-dependent exacerbation of Alzheimer's disease neuropathophysiology. Sci. Rep. 2019, 9, 1-13. [CrossRef]

242. Keskin, A.D.; Kekuš, M.; Adelsberger, H.; Neumann, U.; Shimshek, D.R.; Song, B.; Nelken, I.; Nelken, I.; Sakmann, B.; Konnerth, A.; et al. BACE inhibition-dependent repair of Alzheimer's pathophysiology. Proc. Natl. Acad. Sci. USA 2017, 114, 8631-8636. [CrossRef]

243. Busche, M.A.; Eichhoff, G.; Adelsberger, H.; Abramowski, D.; Wiederhold, K.-H.; Haass, C.; Staufenbiel, M.; Konnerth, A.; Garaschuk, O. Clusters of Hyperactive Neurons Near Amyloid Plaques in a Mouse Model of Alzheimer's Disease. Science 2008, 321, 1686-1689. [CrossRef]

244. Bero, A.W.; Yan, P.; Roh, J.H.; Cirrito, J.R.; Stewart, F.R.; Raichle, M.E.; Lee, J.-M.; Holtzman, D.M. Neuronal activity regulates the regional vulnerability to amyloid- $\beta$ deposition. Nat. Neurosci. 2011, 14, 750-756. [CrossRef]

245. Rodriguez, G.A.; Barrett, G.M.; Duff, K.E.; Hussaini, S.A. Chemogenetic attenuation of neuronal activity in the entorhinal cortex reduces $\mathrm{A} \beta$ and tau pathology in the hippocampus. PLoS Biol. 2020, 18, e3000851. [CrossRef] [PubMed]

246. Yamamoto, K.; Tanei, Z.-I.; Hashimoto, T.; Wakabayashi, T.; Okuno, H.; Naka, Y.; Yizhar, O.; Fenno, L.E.; Fukayama, M.; Bito, H.; et al. Chronic Optogenetic Activation Augments A $\beta$ Pathology in a Mouse Model of Alzheimer Disease. Cell Rep. 2015, 11, 859-865. [CrossRef]

247. Yuan, P.; Grutzendler, J. Attenuation of $\beta$-Amyloid Deposition and Neurotoxicity by Chemogenetic Modulation of Neural Activity. J. Neurosci. 2016, 36, 632-641. [CrossRef]

248. Ju, Y.-E.; Lucey, B.; Holtzman, D.M. Sleep and Alzheimer disease pathology-A bidirectional relationship. Nat. Rev. Neurol. 2014, 10, 115-119. [CrossRef] [PubMed]

249. Iliff, J.J.; Wang, M.; Liao, Y.; Plogg, B.A.; Peng, W.; Gundersen, G.A.; Benveniste, H.; Vates, G.E.; Deane, R.; Goldman, S.A.; et al. A Paravascular Pathway Facilitates CSF Flow Through the Brain Parenchyma and the Clearance of Interstitial Solutes, Including Amyloid $\beta$. Sci. Transl. Med. 2012, 4, 147ra111. [CrossRef]

250. Götz, J.; Bodea, L.-G.; Goedert, M. Rodent models for Alzheimer disease. Nat. Rev. Neurosci. 2018, 19, 583-598 [CrossRef] [PubMed]

251. Steriade, M.; McCormick, D.; Sejnowski, T.J. Thalamocortical oscillations in the sleeping and aroused brain. Science 1993, 262, 679-685. [CrossRef]

252. Romanella, S.; Roe, D.; Tatti, E.; Cappon, D.; Paciorek, R.; Testani, E.; Rossi, A.; Rossi, S.; Santarnecchi, E. The Sleep Side of Aging and Alzheimer's Disease. Sleep Med. 2021, 77, 209-225. [CrossRef]

253. Rasch, B.; Born, J. About Sleep's Role in Memory. Physiol. Rev. 2013, 93, 681-766. [CrossRef]

254. Héricé, C.; Patel, A.A.; Sakata, S. Circuit mechanisms and computational models of REM sleep. Neurosci. Res. 2019, 140, 77-92. [CrossRef]

255. Karashima, A.; Nakao, M.; Honda, K.; Iwasaki, N.; Katayama, N.; Yamamoto, M. Theta wave amplitude and frequency are differentially correlated with pontine waves and rapid eye movements during REM sleep in rats. Neurosci. Res. 2004, 50, 283-289. [CrossRef]

256. Karashima, A.; Nakamura, K.; Sato, N.; Nakao, M.; Katayama, N.; Yamamoto, M. Phase-locking of spontaneous and elicited ponto-geniculo-occipital waves is associated with acceleration of hippocampal theta waves during rapid eye movement sleep in cats. Brain Res. 2002, 958, 347-358. [CrossRef]

257. Ramirez-Villegas, J.F.; Besserve, M.; Murayama, Y.; Evrard, H.C.; Oeltermann, A.; Logothetis, N.K. Coupling of hippocampal theta and ripples with pontogeniculooccipital waves. Nat. Cell Biol. 2021, 589, 96-102. [CrossRef] [PubMed]

258. Patel, A.A.; McAlinden, N.; Mathieson, K.; Sakata, S. Simultaneous Electrophysiology and Fiber Photometry in Freely Behaving Mice. Front. Neurosci. 2020, 14, 148. [CrossRef]

259. Mufson, E.J.; Mash, D.C.; Hersh, L.B. Neurofibrillary tangles in cholinergic pedunculopontine neurons in Alzheimer's disease. Ann. Neurol. 1988, 24, 623-629. [CrossRef] [PubMed]

260. Parvizi, J.; Van Hoesen, G.W.; Damasio, A. The selective vulnerability of brainstem nuclei to Alzheimer's disease. Ann. Neurol. 2001, 49, 53-66. [CrossRef]

261. Bohnen, N.I.; Albin, R.L. The cholinergic system and Parkinson disease. Behav. Brain Res. 2011, 221, 564-573. [CrossRef] [PubMed]

262. Weng, Y.-Y.; Lei, X.; Yu, J. Sleep spindle abnormalities related to Alzheimer's disease: A systematic mini-review. Sleep Med. 2020, 75, 37-44. [CrossRef] 
263. Ngo, H.-V.V.; Martinetz, T.; Born, J.; Mölle, M. Auditory Closed-Loop Stimulation of the Sleep Slow Oscillation Enhances Memory. Neuron 2013, 78, 545-553. [CrossRef]

264. Arzi, A.; Shedlesky, L.; Ben-Shaul, M.; Nasser, K.; Oksenberg, A.; Hairston, I.S.; Sobel, N. Humans can learn new information during sleep. Nat. Neurosci. 2012, 15, 1460-1465. [CrossRef] [PubMed]

265. Ball, W.A.; Morrison, A.R.; Ross, R.J. The effects of tones on PGO waves in slow wave sleep and paradoxical sleep. Exp. Neurol. 1989, 104, 251-256. [CrossRef]

266. Buzsáki, G. Rhythms of the Brain; Oxford University Press (OUP): New York, NY, USA, 2006. 